\title{
A three-dimensional model study of methanesulphonic acid to non sea salt sulphate ratio at mid and high-southern latitudes
}

\author{
H. Castebrunet ${ }^{1}$, P. Martinerie ${ }^{1}$, C. Genthon ${ }^{1}$, and E. Cosme ${ }^{1,2}$ \\ ${ }^{1}$ CNRS/Université Joseph Fourier - Grenoble 1, Laboratoire de Glaciologie et Géophysique de l'Environnement, \\ UMR CNRS/INSU 5183, BP 96, 38402 Saint Martin d'Hères cedex, France \\ ${ }^{2}$ CNRS/Université Joseph Fourier - Grenoble 1/Grenoble - Institut National Polytechnique, Laboratoire des Ecoulements \\ Géophysiques et Industriels, UMR CNRS/INSU 5519, BP 53X, 38402 Saint Martin d'Hères, France
}

Received: 17 February 2009 - Published in Atmos. Chem. Phys. Discuss.: 13 July 2009

Revised: 20 October 2009 - Accepted: 1 December 2009 - Published: 16 December 2009

\begin{abstract}
The Antarctic and sub-Antarctic methanesulphonic acid (MSA) to non sea salt sulphate (nssSO ${ }_{4}$ ) ratio is simulated with the Laboratoire de Météorologie Dynamique Atmospheric General Circulation Model including an atmospheric sulphur chemistry module. Spatial variations of the $\mathrm{MSA} / \mathrm{nssSO}_{4}$ ratio in different regions have been suggested to be mostly dependent on temperature or sulphur source contributions. Its past variations in ice cores have been interpreted as related to the DMS precursor source location. Our model results are compared with available field measurements in the Antarctic and sub-Antarctic regions. This suggests that the MSA/nssSO 4 ratio in the extra-tropical south hemisphere is mostly dependent on the relative importance of various DMS oxidation pathways. In order to evaluate the effect of a rapid conversion of dimethyl sulphoxide (DMSO) into MSA, not implemented in the model, the MSA+DMSO to $\mathrm{nsSSO}_{4}$ ratio is also discussed. Using this modified ratio, the model mostly captures the seasonal variations of $\mathrm{MSA} / \mathrm{nssSO}_{4}$ at mid and high-southern latitudes. In addition, the model qualitatively reproduces the bell shaped meridional variations of the ratio, which is highly dependent on the adopted relative reaction rates for the $\mathrm{DMS}+\mathrm{OH}$ addition and abstraction pathways, and on the assumed reaction products of the MSIA+OH reaction. $\mathrm{MSA} / \mathrm{nssSO}_{4}$ ratio in Antarctic snow is fairly well reproduced except at the most inland sites characterized with very low snow accumulation rates. Our results also suggest that atmospheric chemistry plays an important role in the observed decrease of the ratio in snow between coastal regions and central Antarctica. The
\end{abstract}

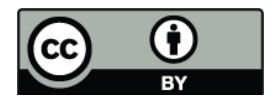

Correspondence to: $\mathrm{H}$. Castebrunet (hcastebrunet@gmail.com) still insufficient understanding of the DMS oxidation scheme limits our ability to model the $\mathrm{MSA} / \mathrm{nssSO}_{4}$ ratio. Specifically, reaction products of the MSIA+OH reaction should be better quantified, and the impact of a fast DMSO conversion to MSA in spring to fall over Antarctica should be evaluated. A better understanding of $\mathrm{BrO}$ source processes is needed in order to include DMS + BrO chemistry in global models. Completing the observations of DMS, BrO and MSA at Halley Bay with DMSO measurements would better constrain the role of $\mathrm{BrO}$ in DMS oxidation. Direct measurements of $\mathrm{MSA}$ and $\mathrm{nssSO}_{4}$ dry deposition velocities on Antarctic snow would improve our ability to model MSA and $\mathrm{nsSSO}_{4}$ in ice cores.

\section{Introduction}

Natural methanesulphonic acid (MSA) and non sea salt sulphate $\left(\mathrm{nssSO}_{4}\right)$ are formed by the oxidation of dimethylsulphide (DMS), produced in the surface ocean by phytoplankton species and subsequently released into the atmosphere. Natural $\mathrm{nssSO}_{4}$ is also produced through the oxidation of sulphur dioxide $\left(\mathrm{SO}_{2}\right)$ emitted by volcanoes and biomass burning. nssSO 4 aerosols also arise from human activities, which are mostly located in the northern hemisphere. $\mathrm{nssSO}_{4}$ aerosols efficiently scatter short wavelength solar radiation. Being efficient cloud condensation nuclei, they can modify the reflectivity of clouds and thus impact on the net solar radiation at the Earth surface and the climate (IPCC, 2007). Assessing how this issue is related to increased anthropogenic activities requires detailed information on what fraction of atmospheric $\mathrm{nssSO}_{4}$ is due to man-made emissions of sulphur

Published by Copernicus Publications on behalf of the European Geosciences Union. 
gases and what fraction is of natural origin (e.g. Kerminen et al., 1998). In order to evaluate those fractions, it is necessary to study the natural sulphur cycle. Sulphur species have relatively short atmospheric lifetimes, thus mid and highsouthern latitudes are still mostly preserved from anthropogenic influence (e.g. Jourdain and Legrand, 2001; Cosme et al., 2005).

Natural sulphur chemistry has been studied for several decades (e.g. Barnes et al., 2006, for a review) (Arimoto et al., 2008; Preunkert et al., 2008; Virkkula et al., 2006, and references therein for recent measurements). In order to estimate the natural oceanic contribution (via DMS) to atmospheric nssSO 4 aerosol concentrations, a widely used approach has been to compare measured MSA to $\mathrm{nssSO}_{4}$ ratio $(\mathrm{R})$ in aerosol particles with an expected ratio resulting from pure atmospheric DMS oxidation (Saltzman et al., 1986; Savoie and Prospero, 1989; Berresheim et al., 1991; Li and Barrie, 1993; Mihalopoulos et al., 1997). This approach has been motivated by the fact that the only known source of MSA is DMS (Saltzman, 1995). Consequently, MSA is considered as a measure of the marine biogenic contribution to sulphur aerosols (Savoie et al., 2002). The ratio R has also been used for Antarctic ice core data interpretation. For instance, Legrand et al. (1992) have proposed to use R as a marker of the latitude of DMS emissions which produced the MSA and $\mathrm{nsSO}_{4}$ measured in Antarctic ice. An optimal use of $\mathrm{R}$ as a marker on a global scale requires that factors such as temperature, light intensity, or oxidant concentrations are well understood (Bates et al., 1992).

Over relatively unpolluted marine areas such as the Southern Ocean, $\mathrm{R}$ displays two main features:

- $\mathrm{R}$ increases towards high-latitudes during summer: The generally accepted explanation is that the rate of MSA production from DMS oxidation increases with decreasing temperature (Hynes et al., 1986; Yin et al., 1990). However, seasonal variations of $R$ at several mid-latitude sites (Ayers et al., 1991; Ayers and Gillett, 2000) as well as in coastal Antarctica (Savoie et al., 1992; Legrand and Pasteur, 1998) show higher values in summer than in winter. This has been interpreted as a decrease of MSA production in winter related to lower $\mathrm{HO}_{2}$ levels (Ayers et al., 1996). Using a 0 dimensional model representing the marine boundary layer, Kerminen et al. (1998) have suggested potential explanations for the meridional behaviour of R: (1) the production of DMSO from DMS oxidation, followed by DMSO to MSA conversion, is favoured at high latitudes, leading to higher MSA yields than at lower latitudes; (2) lower ambient $\mathrm{H}_{2} \mathrm{O}_{2}$ concentrations at high latitudes result in less in-cloud $\mathrm{SO}_{2}$ to sulphate oxidation. Concerning the first hypothesis, the most recent kinetic data evaluations (Atkinson et al., 2006; Sander et al., 2006) confirm an increased production of MSA at low temperature, for temperatures higher than $-42^{\circ} \mathrm{C}$. Below $-42^{\circ} \mathrm{C}$, the reaction speed of the DMS+OH addition channel producing MSA decreases. During summer, when $\mathrm{OH}$ levels are high, this situation occurs near the surface south of $85^{\circ} \mathrm{S}$ or in the free troposphere. Concerning the second point, Cosme et al. (2002) suggested that the main sink of $\mathrm{SO}_{2}$ at high latitudes is aqueous oxidation by ozone, whereas oxidation by $\mathrm{H}_{2} \mathrm{O}_{2}$ dominates at global scale. A detailed analysis of $\mathrm{SO}_{2}$ concentrations and sinks may lead to a better understanding of these processes. However, few $\mathrm{SO}_{2}$ measurements are available at mid and high-southern latitudes. Virkkula et al. (2006) have compared latitudinal variations of $R$ and MSA concentrations with an indicator of anthropogenic aerosol (nitrate). They have found an inverse relationship between R (as well as MSA) and nitrate concentrations. $\mathrm{R}$ increases faster than MSA when nitrate concentrations decrease. Thus, these authors suggest that the increase of $\mathrm{R}$ is more likely explained by a decrease of anthropogenic sulphate than by an increase of natural MSA. However, summer measurements made by Arimoto et al. (2008) in 2003 at South Pole station showed that for inland Antarctica nitrate sources are not necessarily anthropogenic, local emissions from snow being a far more important source of nitrate. Thus, the conclusion of Virkkula et al. (2006) is probably limited to latitudes for which nitrate is dominantly from anthropogenic sources.

- A large seasonal cycle of $\mathrm{R}$ with a summer maximum and a winter minimum:

The most widely used explanation is the decrease of biological activity during winter (Ayers et al., 1991). Reduced marine DMS emissions lead to a lower production of MSA in the atmosphere. As MSA is only produced by DMS oxidation, its atmospheric concentration is more strongly affected than $\mathrm{nsSSO}_{4}$ which has other sources. Gondwe et al. (2004) have suggested an additional explanation: the photochemical production of $\mathrm{OH}$ radicals which oxidize DMS is very weak during polar night. Then, biological activity and temperature are not the only factors which determine MSA production at high latitudes. Light conditions also are important. $\mathrm{nssSO}_{4}$ production is less sensitive to $\mathrm{OH}$ levels because it is also produced by DMS reaction with $\mathrm{NO}_{3}$, followed by $\mathrm{SO}_{2}$ oxidation by ozone and $\mathrm{H}_{2} \mathrm{O}_{2}$ in aqueous phase.

Several modelling studies of the MSA to $\mathrm{nsSSO}_{4}$ ratio have been performed using chemistry box models (e.g. Ayers et al., 1996; Kerminen et al., 1998; Campolongo et al., 1999; Koga and Tanaka, 1999). Such an approach enables to deal with a complex chemistry but may become insufficient for long time scales, when transport becomes a major process in the sulphur cycle. This is the case at high-southern latitudes during winter (Cosme et al., 2005) for instance. Despite the 
numerous gaps in the present understanding of the Antarctic and sub-Antarctic sulphur cycle, some three-dimensional models successfully reproduce its main features (Chin et al., 2000; Cosme et al., 2002, 2005; Gondwe et al., 2004; Castebrunet et al., 2006). Although not perfect, these models are now able to provide realistic information on the present and past sulphur cycle. Gondwe et al. (2004) focussed their threedimensional chemistry-transport model study on global variations of R. Considering all sulphur sources (natural and anthropogenic), this model leads to a $23 \%$ over-estimation of the global $\mathrm{R}$ values. Taking into account only DMS sources, calculated $\mathrm{R}$ values are 3 times higher than observed values, and a significant bias is obtained at coastal Antarctic stations. This over-estimation may be explained by the direct production of MSA from DMS in the chemistry scheme (DMSO is not represented) and the coarse model resolution (Gondwe et al., 2004).

In the present paper, the "LMD-ZT version 4 AntarcticSulphur" model, an Atmospheric General Circulation Model (AGCM) optimized for the Antarctic region and embedding a sulphur module is used to simulate $\mathrm{R}$ at mid- and highsouthern latitudes. Our results are compared with atmospheric measurements in the South Pacific Ocean, at five coastal Antarctic sites, and on the Antarctic plateau. Modelled and observed R in Antarctic snow are also compared. After a description of the DMS oxidation scheme and its major uncertainties (Sect. 2), a second part of this manuscript focuses on the "LMD-ZT version 4 Antarctic-Sulphur" model and its evaluation (Sect. 3). Results are presented in the following sections: modelled seasonal (Sect. 4) and meridional (Sect. 5) variations of $\mathrm{R}$, as well as its spatial distribution in Antarctic snow (Sect. 6), are compared with observations and discussed, finally leading to the concluding section (Sect. 7).

Using sensitivity tests, this study aims at better understanding the major processes responsible for the seasonal and meridional variations of $\mathrm{R}$ in the extra-tropical Southern Hemisphere. Although the complex multiphase sulphur cycle is not fully represented in our simplified global model, we discuss missing processes in terms of model discrepancies with observations. In relation with Antarctic ice core data and the past sulphur cycle, we take into account the recently published seasonality of $\mathrm{R}$ over the Antarctic continent and discuss MSA to $\mathrm{nssSO}_{4}$ ratios in snow.

\section{The oxidation of DMS}

DMS may be oxidized by a number of species $\left(\mathrm{OH}, \mathrm{NO}_{3}\right.$, $\mathrm{BrO}, \mathrm{O}_{3}$, etc.). In unpolluted atmospheres, nitrogen oxide (NOx) concentrations are low and oxidation by $\mathrm{OH}$ dominates (Saltzman, 1995). DMS oxidation by $\mathrm{OH}$ radicals is a complex process that may occur through two chemical pathways: abstraction or addition (Saltzman, 1995). Unlike abstraction, the addition channel requires the presence of oxygen molecules (e.g. Atkinson et al., 2006). Kinetic constants are relatively well known (e.g Hynes et al., 1986; Williams et al., 2001) although they have been recently re-evaluated (Atkinson et al., 2006; Sander et al., 2006). Both reactions have a significant dependence on temperature (Barnes et al., 2006): the addition channel is favoured at cold temperatures (above $-42^{\circ} \mathrm{C}$ ) and dominates over the abstraction channel for temperatures lower than approximately $17^{\circ} \mathrm{C}$ (Hynes et al., 1986; Williams et al., 2001; Albu et al., 2006).

Meanwhile, major uncertainties remain on the oxidation products of the addition pathway. Field studies have identified a number of DMS oxidation products such as sulphur dioxide $\left(\mathrm{SO}_{2}\right)$, sulphuric acid $\left(\mathrm{H}_{2} \mathrm{SO}_{4}\right)$, dimethyl sulphoxide $\left(\mathrm{CH}_{3} \mathrm{SOCH}_{3}, \mathrm{DMSO}\right)$, dimethylsulphone $\left(\mathrm{CH}_{3} \mathrm{SO}_{2} \mathrm{CH}_{3}\right.$, $\left.\mathrm{DMSO}_{2}\right)$ and methane sulphonic acid $\left(\mathrm{CH}_{3} \mathrm{~S}(\mathrm{O})_{2} \mathrm{OH}, \mathrm{MSA}\right)$ (e.g. Davis et al., 1998; Jefferson et al., 1998; Mauldin et al., 1999; Chen et al., 2000; de Bruyn et al., 2002). Arsene et al. (1999) suggest that DMSO is the main product of the addition pathway. Several studies observed the production of large amounts of methane sulphinic acid $\left(\mathrm{CH}_{3} \mathrm{~S}(\mathrm{O}) \mathrm{OH}\right.$, MSIA) by the DMSO+OH reaction (Urbanski et al., 1998; Arsene et al., 1999, 2002; Kukui et al., 2003). MSIA also reacts with $\mathrm{OH}$, but its oxidation products are poorly identified (Sander et al., 2006). However, this reaction was found to be temperature-dependent and to produce preferentially $\mathrm{SO}_{2}$ (Arsene et al., 1999, 2002; Kukui et al., 2003). On the other hand, MSA has been proposed as the main product of DMSO oxidation (Davis et al., 1998; Bardouki et al., 1999). Overall, the gaseous MSA production pathways are still highly uncertain. For instance Karl et al. (2007) stress the role of $\mathrm{CH}_{3} \mathrm{SO}_{2}$ thermal decomposition and the poorly understood production and loss pathways of MSIA. On the other hand, Lucas and Prinn (2002) highlight a missing gas phase MSA production pathway and obtain best results when MSA is produced from the oxidation of MSIA.

Several authors have proposed an heterogeneous chemical process in aqueous phase or on wet aerosols, oxidizing DMSO faster than in the gas phase (Ravishankara et al., 1997; Davis et al., 1998; Sciare et al., 2000). Legrand et al. (2001) suggested that the presence of $\mathrm{OH}$ is necessary for this reaction. Other species oxidize DMS. Oxidation by nitrate radicals $\left(\mathrm{NO}_{3}\right)$ follows an abstraction pathway and predominantly produces $\mathrm{SO}_{2}$ (e.g. Barnes et al., 2006). Although $\mathrm{NO}_{3}$ is quickly destroyed by photolysis during the day, its concentration sharply increases during polar night and this reaction becomes an important DMS sink. DMS is also oxidized by ozone, producing DMSO in aqueous phase (Gershenzon et al., 2001) and $\mathrm{SO}_{2}$ in gaseous phase (Martinez and Herron, 1978). These reactions may have an important role at high-southern latitudes (Boucher et al., 2003). However, their kinetic constants are still not well known. Halogen oxides react with DMS and have been observed in coastal Antarctica (e.g. Saiz-Lopez et al., 2007). At Halley Bay, DMS should react much faster with $\mathrm{BrO}$ than with $\mathrm{OH}$, leading to a DMS summer lifetime of 0.4 days (Read et al., 2008) or less than $2 \mathrm{~h}$ (Saiz-Lopez et al., 2007). Acidified sea-salt 


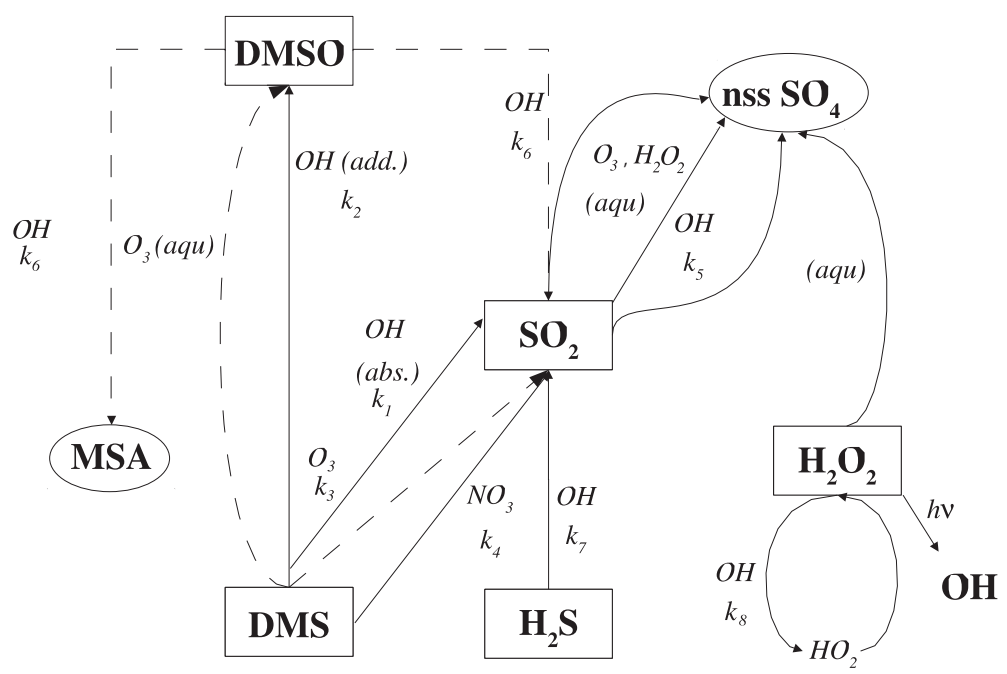

Fig. 1. Sulphur chemistry scheme in the "LMD-ZT version 4 Antarctic-Sulphur" model. Species in the gas phase and aerosol phase are respectively represented using square and oval boxes. Dashed lines represent the oxidation channels for which major uncertainties remain.

surfaces such as aerosol, frost flowers and brine, have raised a lot of interest as a source of $\mathrm{BrO}$ in recent investigations (e.g. Wagner et al., 2007; Simpson et al., 2007). Due to the short lifetime of $\mathrm{BrO}$, it should affect mostly coastal Antarctica. However, as $\mathrm{BrO}$ is also observed in continental air masses, Saiz-Lopez et al. (2007) suggested that $\mathrm{BrO}$ production could also occur on sea-salt in surface Antarctic snow. Although the observed high levels of halogen oxides should rapidely deplete ozone and DMS, their concentrations show no clear anti-correlations (Saiz-Lopez et al., 2007) (Fig. 1 in Read et al., 2008). Besides the reaction of DMS with BrO, von Glasow and Crutzen (2004) considered more complex gas phase and aqueous phase interactions of sulphur species with halogens. In this frame, both MSA and $\mathrm{nsSSO}_{4}$ productions are modified, but the chemical mechanism is uncompletely constrained (e.g. unknown branching ratios). von Glasow and Crutzen (2004) stress the fact that gas phase DMS + BrO chemistry strongly emphasize the effects of the uncertainty on the end-products of DMS oxidation, due to the uncertainties on the products of the MSIA $+\mathrm{OH}$ reaction.

It is generally admitted that nssSO 4 and MSA are the two major final products of the above DMS oxidation processes. $\mathrm{SO}_{2}$ reacts with $\mathrm{OH}$ in the gas phase and with $\mathrm{O}_{3}$ and $\mathrm{H}_{2} \mathrm{O}_{2}$ in the liquid phase to produce sulphuric acid $\left(\mathrm{H}_{2} \mathrm{SO}_{4}\right)$ which can condensate into particles. nssSO $\mathrm{S}_{4}$ and MSA aerosols are removed from the atmosphere by dry deposition or precipitation (scavenging).

\section{3 "LMD-ZT version 4 Antarctic-Sulphur" model}

\subsection{Description}

This study uses an updated version of the "LMD-ZT Antarctic-Sulphur" global model described by Cosme et al. (2002). The Atmospheric General Circulation Model (AGCM) is developed by the Laboratoire de Météorologie Dynamique (LMD, Paris, France). Here, we use its version 4, which takes into account fractional sea-ice and updated sea-surface temperatures (Taylor et al., 2000). The grid was stretched to provide a higher resolution in the Antarctic region than in the rest of the globe and the standard hybrid $\sigma$-pressure vertical discretization was modified in order to obtain a better resolution in the boundary layer (Krinner et al., 1997). Here, the model is run on a grid of 96 (longitude) $\times 72$ (latitude) points, with 19 vertical levels. The mean elevation of the first 6 layers above the surface is 3 , $9,21,44,82$ and $141 \mathrm{~m}$. The surface and boundary layer parameterizations are modified to better account for the specificities of the atmospheric physics in polar regions (Krinner et al., 1997). As the data used are multi year average values with site-dependent available years, the model is run in climate mode rather than constrained with meteorological data.

The sulphur module was first developed by Pham et al. (1995); Boucher et al. (2002). Four sulphur gases, DMS, $\mathrm{SO}_{2}$, hydrogen sulphide $\left(\mathrm{H}_{2} \mathrm{~S}\right)$ and dimethylsulphoxide (DMSO), and two sulphur aerosols, $\mathrm{nssSO}_{4}$ and MSA, are calculated on-line. Surface emissions of DMS, $\mathrm{SO}_{2}$, and $\mathrm{H}_{2} \mathrm{~S}$ are considered. They are prescribed as in Boucher et al. (2002) and Cosme et al. (2005), taking into account DMS and $\mathrm{H}_{2} \mathrm{~S}$ fluxes from the biosphere, background volcanic emissions of $\mathrm{SO}_{2}, \mathrm{SO}_{2}$ fluxes from biomass burning, 
and anthropogenic emissions of $\mathrm{SO}_{2}$ and $\mathrm{H}_{2} \mathrm{~S}$. The DMS fluxes from the ocean are derived from the sea surface DMS concentrations maps of Kettle et al. (1999) using the seato-air flux parameterization of Liss and Merlivat (1986). It should be noted that available estimates of DMS concentrations in the Southern ocean are based on limited measurements and subject to significant uncertainties (e.g. Cosme et al., 2002; Boucher et al., 2003). A comparison of the extrapolated maps from Kettle et al. (1999) with the NOAA-PMEL (2009) database is provided in the supplementary material. http://www.atmos-chem-phys.net/9/9449/ 2009/acp-9-9449-2009-supplement.pdf $\mathrm{SO}_{2}$, DMSO, MSA and $\mathrm{nsSSO}_{4}$ undergo dry deposition. To our knowledge, no direct measurements of dry deposition velocites of sulphur aerosols on snow were performed. The deposition fluxes of $\mathrm{nsSSO}_{4}$ were thus adjusted to fit concentration measurements in snow and ice (Legrand et al., 1997; Minikin et al., 1998). Due to uncertainties on air-snow exchanges of MSA (see e.g. Castebrunet et al., 2006, for a discussion), equal deposition velocities are prescribed for MSA and $\mathrm{nsSSO}_{4}$. This leaded to an important reduction dry deposition with respect to Cosme et al. (2002). Scavenging is performed in cloud for all species and below clouds only for sulphur aerosols. The oxidant concentrations, hydroxyl $(\mathrm{OH})$, nitrate $\left(\mathrm{NO}_{3}\right)$ and ozone $\left(\mathrm{O}_{3}\right)$, are prescribed (Müller and Brasseur, 1995). The concentration of hydrogen peroxide $\left(\mathrm{H}_{2} \mathrm{O}_{2}\right)$ is computed online (Boucher et al., 2003).

The chemistry scheme (Fig. 1) was updated using the most recent kinetic data of the IUPAC subcommittee (Atkinson et al., 2006) and the NASA panel for data evaluation (Sander et al., 2006). Table 1 presents the updated reaction rates and branching ratios (Castebrunet, 2007) with the references used. The most important changes deal with the kinetic constants of the addition channel of DMS oxidation, and DMSO oxidation. The addition channel of DMS oxidation by $\mathrm{OH}$ leads to DMSO only (Hynes et al., 1986; Arsene et al., 1999), whereas the abstraction channel leads to $\mathrm{SO}_{2}$ only. Based on Arsene et al. (1999, 2002), we assumed that the gas phase reaction of DMSO with $\mathrm{OH}$ produces MSIA, which is further oxidized into MSA and $\mathrm{SO}_{2}$. We derived our temperaturedependent branching ratios between these two species from Table 2 in Arsene et al. (1999). Being based on few measurements, these branching ratios are speculative (Castebrunet, 2007); however, they define the only pathway to MSA in the $\mathrm{OH}$ driven DMS oxidation scheme (Fig. 1). Our use of temperature-dependent branching ratios and MSA production from the DMS $+\mathrm{OH}$ addition branch going through DMSO follows recommendations of Lucas and Prinn (2005). $\mathrm{nssSO}_{4}$ can be formed through $\mathrm{SO}_{2}$ oxidation, by $\mathrm{OH}$ in the gas phase, or by $\mathrm{O}_{3}$ and $\mathrm{H}_{2} \mathrm{O}_{2}$ in the aqueous phase. No liquid cloud and thus no aqueous chemistry are present in the model below $-30^{\circ} \mathrm{C}$. The aqueous chemistry scheme is described in Boucher et al. (2002), Henry's law is assumed for gas-liquid phase transfers and aqueous reactions are $\mathrm{pH}$ dependent. The oxidation reactions of DMS by ozone in aqueous and gas phases, leading respectively to DMSO and $\mathrm{SO}_{2}$, are tested in specific simulations as their kinetic constants are subject to large uncertainties. As in Boucher et al. (2003), we use the aqueous reaction rate estimated by Gershenzon et al. (2001) and the upper limit given by Martinez and Herron (1978) for the gas phase reaction.

Two potentially important processes are not represented in the model chemistry scheme. Field measurements in coastal Antarctica suggest that DMSO can be captured at the surface of aerosols (Davis et al., 1998), and then be oxidized by $\mathrm{OH}$, leading to MSA directly in the aerosol phase (Legrand et al., 2001). This process may significantly reduce the lifetime of DMSO in summer. The potential impact of this reaction was estimated through sensitivity tests (Cosme et al., 2002). A full 3-D model implementation of this reaction would require to include and validate a background aerosols module which is not currently available in the model. Similarly, DMS oxidation by BrO is known to be potentially important, especially in spring (e.g. Read et al., 2008, and references therein). Sensitivity tests performed with fixed $\mathrm{BrO}$ concentrations have shown the potential impact of this reaction (Boucher et al., 2003; Preunkert et al., 2008). The implementation of this process in the model would require the calculation of $\mathrm{BrO}$ sources and photochemistry. However, the current knowledge of $\mathrm{BrO}$ production in snow and on sea-ice is insufficient to permit a full modelling. Besides, as $\mathrm{BrO}$ interacts with other oxidants such as $\mathrm{O}_{3}$ and $\mathrm{OH}$, the calculation of DMS interactions with $\mathrm{BrO}$ would require a re-evaluation of other oxidant fields (see e.g. von Glasow and Crutzen, 2004).

Five year simulations are used in this study. The first year allows for model spin up and is discarded. The results presented below are averaged over the last four simulated years. Four simulations are discussed. Simulation REF is the reference, with no anthropogenic sulphur source. Simulation REF-ANTH takes into account anthropogenic sulphur emissions. Simulations $\mathrm{TESTO}_{3}$ and $\mathrm{TESTO}_{3}$-ANTH (with anthropogenic emissions) include DMS oxidation by ozone, thus testing a more complete representation of DMS oxidation pathways.

\subsection{Model evaluation}

Dumont d'Urville (Coastal Antarctica: $140.16^{\circ} \mathrm{E}, 66.66^{\circ} \mathrm{S}$ ) and Amsterdam Island (sub Antarctic: $77.3^{\circ} \mathrm{E}, 37.50^{\circ} \mathrm{S}$ ) are the only stations where most of the modelled sulphur species (DMS, DMSO, MSA and $\mathrm{nssSO}_{4}$ ) atmospheric concentrations are continuously measured (CESOA, 2007; Preunkert et al., 2007). Therefore, we select these two stations for primary model evaluation. Results at some additional measurement stations are described in Castebrunet (2007) and in the supplementary material http://www.atmos-chem-phys.net/ 9/9449/2009/acp-9-9449-2009-supplement.pdf. Figure 2 compares the observed and simulated seasonal variations. The model (simulation REF, in blue) reproduces most 

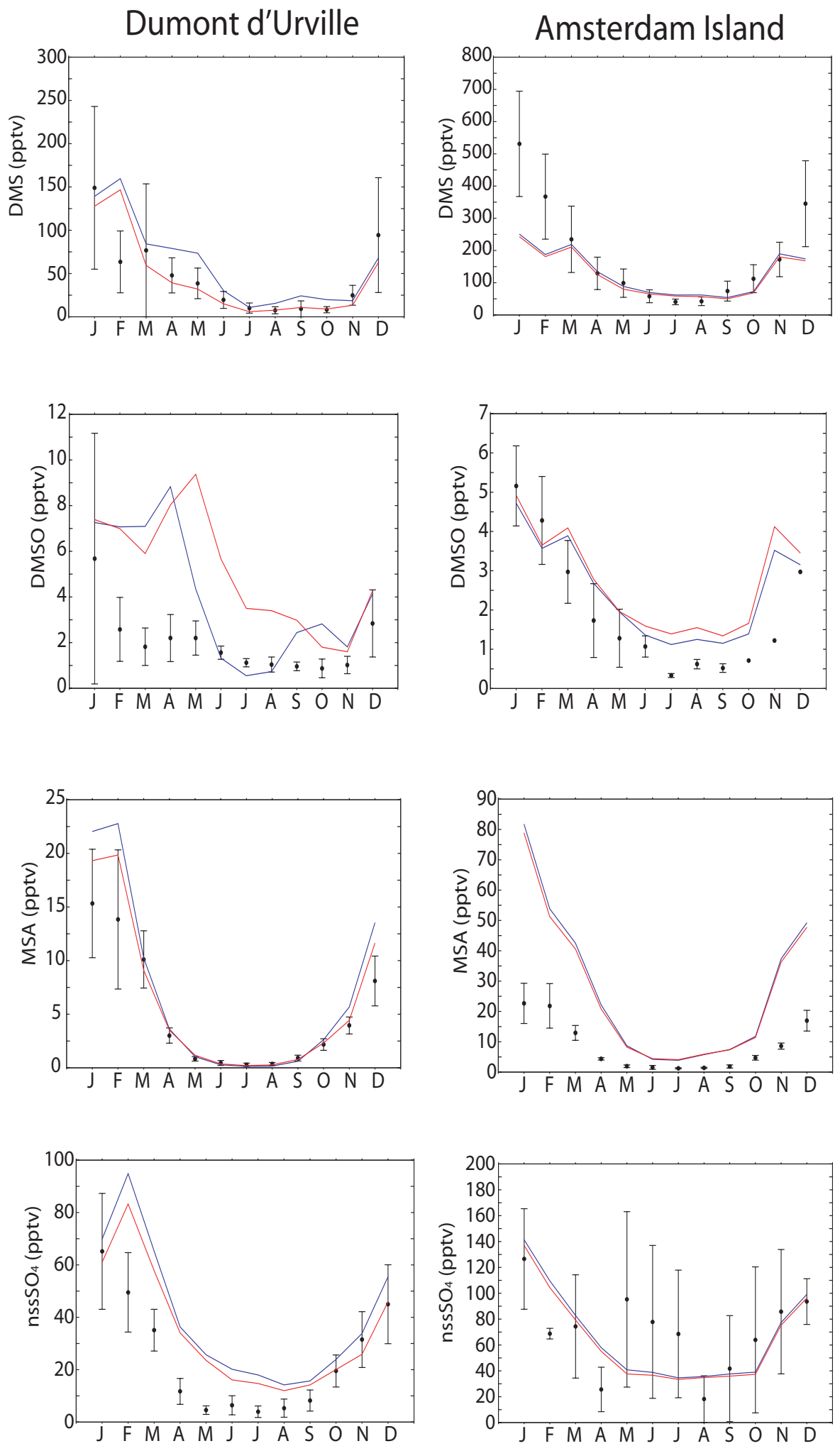

Fig. 2. Observed (circles) and simulated mean seasonal variations of sulphur species at Dumont d'Urville (left panel) and Amsterdam Island (right panel), for simulations REF (blue) and $\mathrm{TESTO}_{3}$ (red). Inter-annual variability of measured species is represented (black bars). Data originate from Preunkert et al. (2007, 2008); CESOA (2007) and cover the 1998-2006 period for Dumont d'Urville. At Amsterdam Island, the data cover 1987-2006, 1997-2006 and 2003-2006 periods for respectively DMS, DMSO and sulphur aerosols 
Table 1. Sulphur oxidation mechanism in the "LMD-ZT version 4 Antarctic-Sulphur" model.

\begin{tabular}{|c|c|c|}
\hline Gas phase reactions & Kinetic constants & References \\
\hline $\mathrm{DMS}+\mathrm{OH} \rightarrow \mathrm{SO}_{2}$ & $\mathrm{~K}_{1}=1.12 \times 10^{-11} \exp ^{-250 / T}$ & (Atkinson et al., 2006) \\
\hline $\mathrm{DMS}+\mathrm{OH} \rightarrow \mathrm{DMSO}$ & $\mathrm{K}_{2}=\frac{9.5 \times 10^{-39}\left[\mathrm{O}_{2}\right] \exp ^{5270 / T}}{1+7.5 \times 10^{-29}\left[\mathrm{O}_{2}\right] \exp ^{5610 / T}}$ & (Atkinson et al., 2006) \\
\hline Test: $\mathrm{DMS}+\mathrm{O}_{3} \rightarrow \mathrm{SO}_{2}$ & $\mathrm{~K}_{3}=8.3 \times 10^{-19}$ & (Martinez and Herron, 1978) \\
\hline $\mathrm{DMS}+\mathrm{NO}_{3} \rightarrow \mathrm{SO}_{2}$ & $\mathrm{~K}_{4}=1.9 \times 10^{-13} \exp ^{520 / T}$ & (Atkinson et al., 2006) \\
\hline $\mathrm{SO}_{2}+\mathrm{OH} \rightarrow$ sulphate & $\begin{array}{l}\mathrm{K}_{5}=\frac{\mathrm{k}_{0}}{1+\frac{\mathrm{k}_{0}}{\mathrm{k}_{\text {inf }}}} \mathrm{Fc}^{\left[1+\left(\log \frac{\mathrm{k}_{0}}{\mathrm{k}_{\text {inf }}}\right)^{2}\right]^{-1}} \\
\mathrm{k}_{0}=4.5^{-31}[\mathrm{M}](300 / T)^{3.9} \\
\mathrm{k}_{\mathrm{inf}}=1.3 \times 10^{-12}(300 / T)^{0.7} \\
\mathrm{Fc}=0.525\end{array}$ & (Atkinson et al., 2006) \\
\hline $\mathrm{DMSO}+\mathrm{OH} \rightarrow \beta_{\mathrm{SO}_{2}} \mathrm{SO}_{2}+\beta_{\mathrm{MSA}} \mathrm{MSA}$ & $\begin{array}{l}\mathrm{K}_{6}=6.1^{-12} \exp ^{800 / T} \\
\beta_{\mathrm{SO}_{2}}=-0.0123(T-320) \text { and } \beta_{\mathrm{MSA}}=1-\beta_{\mathrm{SO}_{2}}\end{array}$ & $\begin{array}{l}\text { (Sander et al., 2006) } \\
\text { estimated from Arsene et al. (1999) }\end{array}$ \\
\hline $\mathrm{H}_{2} \mathrm{~S}+\mathrm{OH} \rightarrow \mathrm{SO}_{2}$ & $\mathrm{~K}_{7}=6 \times 10^{-12} \exp ^{-80 / T}$ & (Atkinson et al., 2006) \\
\hline $\mathrm{HO}_{2}+\mathrm{HO}_{2} \rightarrow \mathrm{H}_{2} \mathrm{O}_{2}$ & $\mathrm{~K}_{8}=3.5 \times 10^{-13} \exp ^{430 / T}+1.7 \times 10^{-33}[M] \exp ^{1000 / T}$ & (Sander et al., 2006) \\
\hline $\mathrm{H}_{2} \mathrm{O}_{2}+\mathrm{h} \nu \rightarrow 2 \mathrm{OH}$ & Tabulated values & (Müller and Brasseur, 1995) \\
\hline \multicolumn{3}{|l|}{ Aqueous phase reactions } \\
\hline $\mathrm{S}_{\mathrm{IV}}+\mathrm{H}_{2} \mathrm{O}_{2} \rightarrow$ sulphate & $\begin{array}{l}\mathrm{K}_{10}^{\mathrm{aqu}}=7.5 \times 10^{7} \exp ^{-4430\left(\frac{1}{T}-\frac{1}{298}\right)} \frac{\left[H^{+}\right]_{\mathrm{aq}}}{1+13\left[H^{+}\right]} \\
\mathrm{K}_{11}^{\mathrm{aqu}}=2.4 \times 10^{4}\end{array}$ & (Seinfeld and Pandis, 1998) \\
\hline $\mathrm{S}_{\mathrm{IV}}+\mathrm{O}_{3} \rightarrow$ sulphate & $\begin{array}{l}\mathrm{K}_{12}^{\mathrm{aqu}}=3.7 \times 10^{5} \exp ^{-5530\left(\frac{1}{T}-\frac{1}{298}\right)} \\
\mathrm{K}_{13}^{\mathrm{aqu}}=1.5 \times 10^{9} \exp ^{-5280\left(\frac{1}{T}-\frac{1}{298}\right)}\end{array}$ & (Seinfeld and Pandis, 1998) \\
\hline Test: $\mathrm{DMS}+\mathrm{O}_{3} \rightarrow \mathrm{DMSO}$ & $\mathrm{K}_{14}^{\mathrm{aqu}}=5.3 \times 10^{12} \exp ^{-2600 / T}$ & (Gershenzon et al., 2001) \\
\hline
\end{tabular}

Units: reaction rates are in $\mathrm{cm}^{3}$ molec ${ }^{-1} \mathrm{~s}^{-1}$ for the gas phase, and in $\mathrm{L} \mathrm{mol}^{-1} \mathrm{~s}^{-1}$ for the aqueous phase.

$S_{\text {IV }}$ : sulphate at the oxidation state 4.

aspects of the seasonal cycle of sulphur species. Compared to the previous reference version (Cosme et al., 2002), major changes in model configuration were performed: the shift from version 3 to version 4 of the atmospheric circulation model, and the update of the chemistry scheme (see Sect. 3.1). Moreover, lateral nudging by meteorological analyses of the atmospheric circulation at mid-southern latitudes is not used as in Cosme et al. (2002) because a major aim of developing and validating this model is climate change studies (Castebrunet et al., 2006). Despite these changes and although measurements cover a longer period, present results remain globally consistent with those of Cosme et al. (2002) (not shown) and with the observations (Fig. 2). DMS concentrations are somewhat under-estimated in summer at Amsterdam Island, especially due to the absence of lateral nudging and the upgrade of the atmospheric circulation model. On the other hand, the previously over-estimated DMS levels at Dumont d'Urville are now consistent with data. We should note that summer DMS concentrations are strongly related to local emission fluxes (Cosme et al., 2002; Preunkert et al., 2007) and thus to local winds. Because it has a short lifetime, DMSO is particularly sensitive to the chemistry scheme. As in Cosme et al. (2002), the heterogeneous oxidation of DMSO on aerosols, not taken into account in the model, is the most likely reason for the model over-estimation of DMSO in summer and fall at Dumont d'Urville, and spring at Amsterdam Island. The fact that summer results at Amsterdam Island are unaffected is surprising at first glance but may result from a compensating effect of under-estimated DMS concentrations. Implementing a DMS aqueous phase 
Table 2. $\mathrm{R}$ observed and modelled ( $\mathrm{R}_{\mathrm{psim}}$, simulation $\left.\mathrm{REF}-\mathrm{ANTH}\right)$ at all studied stations. Winter and summer values as well as annual means are provided. Winter refers to the period from May to September and summer to that from December to February.

\begin{tabular}{|c|c|c|c|c|c|c|c|}
\hline \multirow[t]{2}{*}{ Station } & \multirow[t]{2}{*}{ Location } & \multicolumn{3}{|c|}{ Model } & \multicolumn{3}{|c|}{ Observations } \\
\hline & & Winter & Summer & Mean & Winter & Summer & Mean \\
\hline Amsterdam I. & $37^{\circ} 50 \mathrm{~S}$ & 0.11 & 0.49 & 0.35 & 0.02 & 0.23 & 0.11 \\
\hline Cape Grim & $40^{\circ} 41 \mathrm{~S}$ & 0.04 & 0.37 & 0.22 & 0.13 & 0.39 & 0.24 \\
\hline Palmer & $64^{\circ} 77 \mathrm{~S}$ & 0.12 & 0.58 & 0.46 & 0.16 & 0.54 & 0.36 \\
\hline Dumont d'Urville & $66^{\circ} 40 \mathrm{~S}$ & 0.12 & 0.36 & 0.28 & 0.11 & 0.23 & 0.17 \\
\hline Mawson & $67^{\circ} 60 \mathrm{~S}$ & 0.14 & 0.28 & 0.24 & 0.27 & 0.23 & 0.24 \\
\hline Neumayer & $70^{\circ} 39 \mathrm{~S}$ & 0.15 & 0.40 & 0.31 & 0.08 & 0.34 & 0.19 \\
\hline Halley Bay & $75^{\circ} 39 \mathrm{~S}$ & 0.13 & 0.33 & 0.26 & 0.09 & 0.32 & 0.17 \\
\hline Kohnen & $75^{\circ} \mathrm{S}$ & 0.11 & 0.20 & 0.18 & $<0.27$ & 0.17 & 0.20 \\
\hline Dome C & $75^{\circ} 06 \mathrm{~S}$ & 0.13 & 0.19 & 0.19 & 0.17 & 0.08 & 0.19 \\
\hline South Pole & $90^{\circ} \mathrm{S}$ & 0.10 & 0.18 & 0.19 & - & 0.06 & - \\
\hline
\end{tabular}

reaction with ozone (simulation $\mathrm{TESTO}_{3}$, in red), which produces DMSO, improves model results for DMS at Dumont d'Urville in April-May, but induces an over-estimation of DMSO in winter at this station. On the other hand, it leads to very little changes at Amsterdam Island. We attribute this behaviour to the absence of polar night at Amsterdam Island and thus to an effective DMS oxidation by $\mathrm{OH}$ in all seasons. The most prominent discrepancy with respect to observations is an over-estimation of MSA at Amsterdam Island. A strong increase of MSA at this site was obtained after implementation of the new chemistry scheme (Table 1): indeed, the updated branching ratio of the $\mathrm{DMSO}+\mathrm{OH}$ reaction depends on temperature and leads to an increase of MSA production (at least above $-20^{\circ} \mathrm{C}$ ) compared to the previous chemistry scheme (Cosme et al., 2002). A rather similar behaviour is obtained at Cape Grim (see supplementary material, http://www.atmos-chem-phys.net/9/9449/ 2009/acp-9-9449-2009-supplement.pdf), although this site is also sensitive to the changes in model dynamics (Castebrunet, 2007). On the other hand, the previously underestimated MSA levels at Dumont d'Urville are now well reproduced, despite a slight over-estimation in summer suggesting that the temperature-dependent branching ratio of $\mathrm{DMSO}+\mathrm{OH}$ could produce too much MSA for the higher temperatures of the mid-latitudes. $\mathrm{nsSSO}_{4}$ concentrations are somewhat over-estimated at Dumont d'Urville, whereas they were under-estimated in Cosme et al. (2002). This change is again mostly due to the combined effect of the removal of circulation nudging and the shift to the updated version of the model (version 4). At Amsterdam Island, model nssSO results are consistent with the highly variable measurements.

Seasonal variations of sulphur aerosols were recently measured in the interior of the Antarctic continent, at Dome C $\left(123.21^{\circ} \mathrm{E}, 75.06^{\circ} \mathrm{S}\right)$ in $2005-2006$ (Preunkert et al., 2008) and at Kohnen station $\left(0^{\circ} \mathrm{E}, 75.0^{\circ} \mathrm{S}\right)$ in 2003-2006 (Piel et al., 2006; Weller and Wagenbach, 2007). A major difference between the two sites is their distance from the coast:
$520 \mathrm{~km}$ and $1000 \mathrm{~km}$ respectively for Kohnen and Dome C stations, whereas their similar latitudes imply almost identical photolytic conditions. DMS was also measured at Dome C (Preunkert et al., 2008). The model qualitatively reproduces the DMS seasonal cycle with a winter maximum, but strongly over-estimates its concentrations (see supplementary material, http://www.atmos-chem-phys.net/9/9449/ 2009/acp-9-9449-2009-supplement.pdf). At least for the months in which the polar night is not complete, the boundary layer chemistry related to air-snow exchanges, which produces very high $\mathrm{OH}$ levels (Mauldin et al., 2004), is not taken into account here. Moreover, the lack of $\mathrm{NO}_{3}$ measurements over Antarctica (Jones et al., 2007) prevents the evaluation of the prescribed $\mathrm{NO}_{3}$ levels. Thus the over-estimation of DMS concentrations at Dome $\mathrm{C}$ could be due to biased oxidant levels in the boundary layer. Figure 3 presents the seasonal variations of MSA and $\mathrm{nssSO}_{4}$ at the two inland stations. The model represents the main features of their seasonal behaviour, with higher values in summer than in winter. As at Dumont d'Urville, the modelled seasonality shows a peak in February for both aerosols, which is not consistent with observations. Because this peak also characterizes the modelled seasonal cycle of DMS at the coast (Fig. 2), this feature may indicate that sulphur aerosols are sensitive to the DMS sources in the model, even over the Antarctic plateau. The over-estimation of $\mathrm{nssSO}_{4}$ at Dumont d'Urville is amplified at inland sites particularly at Dome C. It leads to significant modelled winter levels whereas observations are close to zero. Modelled MSA concentrations are slightly over-estimated during summer compared to mean observed values at Kohnen station. The lack of $\mathrm{OH}$ during polar night results in a quasi absence of MSA during winter in model results, as observed at both stations. On the other hand, as for $\mathrm{nsSSO}_{4}$, the model strongly over-estimates MSA in summer at Dome C. The over-estimation of sulphur aerosols inside the continent, especially marked at Dome $\mathrm{C}$ and for $\mathrm{nssSO}_{4}$, is mainly linked with the update of the 

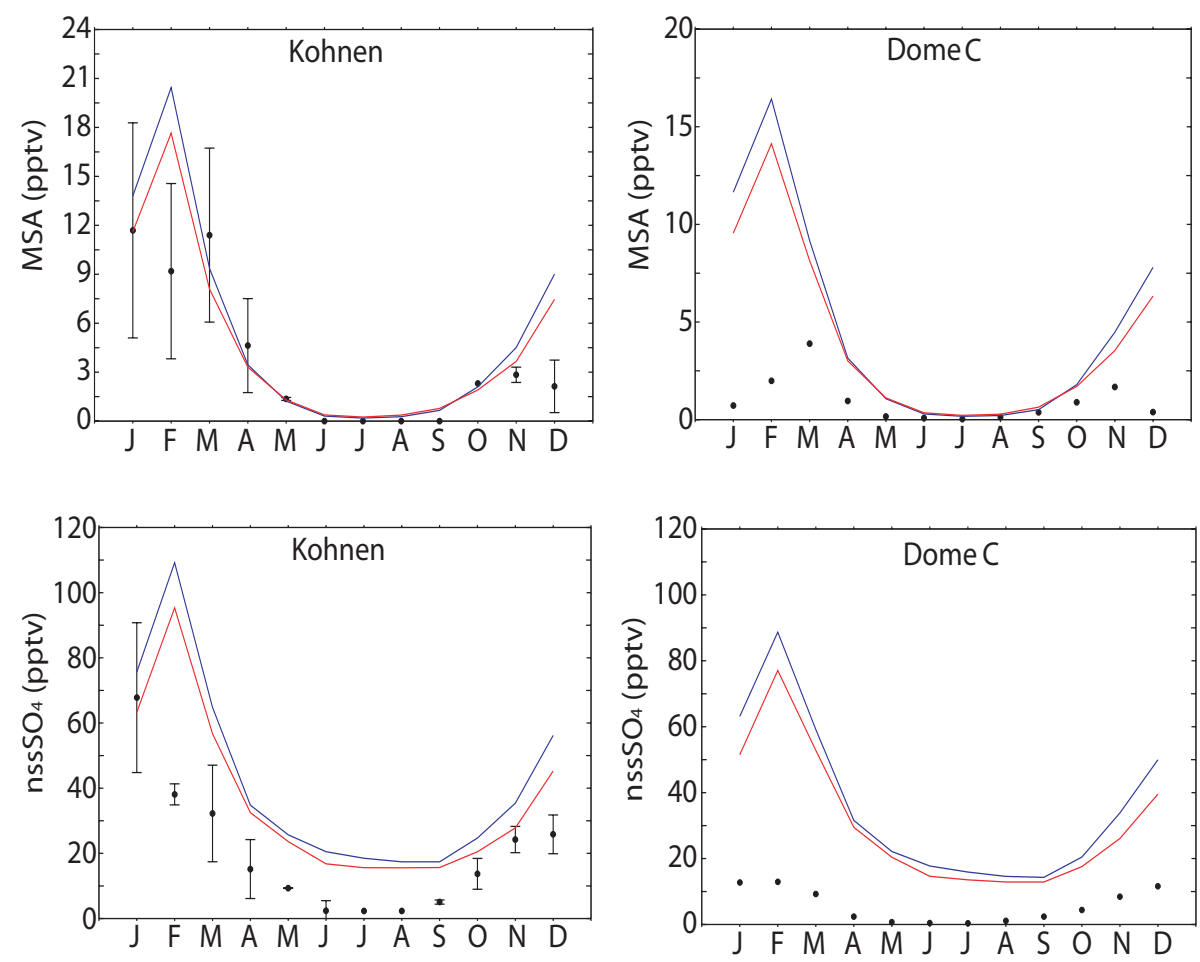

Fig. 3. Seasonal variations of MSA and $\mathrm{nsSSO}_{4}$ at Kohnen and Dome C stations, for simulations REF (blue) and TESTO 3 (red). Available observations (black circles) are mean monthly data from Piel et al. (2006); Weller and Wagenbach (2007) for the 2003-2006 period at Kohnen station with the inter-annual variability (black bars) and mean monthly measurements realised in 2006 (Preunkert et al., 2008) at Dome C.

atmospheric model (version 4) which favours the vertical transport of species (Castebrunet, 2007). It is also dependent on aerosol dry deposition velocities. Here, we use low values evaluated from a few snow/ice records (Castebrunet, 2007). These model characteristics lead to increased lifetimes of sulphur aerosols, allowing a larger homogenization in the atmospheric column and a larger transport from coastal regions to the Antarctic plateau. Increased transport is especially marked for $\mathrm{nssSO}_{4}$ because, MSA being a minor product of DMS oxidation, it is more sensitive to the DMS oxidation pathways than nssSO ${ }_{4}$. Excessive modelled transport is responsible for under-estimated gradient of aerosol loads between the coast and the Antarctic plateau. The observed gradient is probably controlled by the degree of dilution of air masses advected from the coast to the Antarctic plateau as suggested by Weller and Wagenbach (2007); Preunkert et al. (2008). Experimental studies consistently indicate that MSA decreases faster than $\mathrm{nssSO}_{4}$ with distance from the coast (Kärkäs et al., 2005; Arimoto et al., 2008), possibly due to preferential deposition, chemical processes, or $\mathrm{nssSO}_{4}$ sources other than DMS (Arimoto et al., 2008). The model reproduces this feature, and tests showed that it is governed by the temperature dependence of MSA production.

\section{Seasonal variations of the $\mathrm{MSA}$ to $\mathrm{nsSSO}_{4}$ ratio}

The observed MSA to nssSO 4 ratio (called $\mathrm{R}_{\mathrm{obs}}$ ) may be evaluated from measurements in both the atmosphere and snow. Model results will be referred to as $\mathrm{R}_{\text {sim }}$. As discussed in Sect. 3.1, an heterogeneous sink of DMSO producing MSA is likely missing in our chemistry scheme, which could lead to a bias of the MSA to $\mathrm{nsSSO}_{4}$ ratio. Consequently, the (MSA + DMSO) to nssSO 4 ratio $\left(\mathrm{R}_{\mathrm{psim}}\right)$ is also presented and discussed. $\mathrm{R}_{\mathrm{psim}}$ represents the $\mathrm{MSA}$ to $\mathrm{nsSSO}_{4}$ ratio if all DMSO was instantaneously converted into MSA. In this frame, the modelled $R_{\text {sim }}$ and $R_{\text {psim }}$ should bracket the true value of $R$. $R_{\text {psim }}$ is also equivalent to the ratio calculated with models which do not explicitly calculate DMSO, such as in Gondwe et al. (2004).

\subsection{Coastal Antarctic stations}

Model results indicate that south of $55^{\circ} \mathrm{S}$, anthropogenic emissions have little impact on R (Cosme et al., 2005). This is confirmed by experimental data at Dumont d'Urville station (Jourdain and Legrand, 2001). The simulation results with and without anthropogenic sources being almost identical, we do not discuss simulations with anthropogenic emissions in this section. Year-round measurements of MSA and $\mathrm{nssSO}_{4}$ are available from five stations at the Antarctic coast 


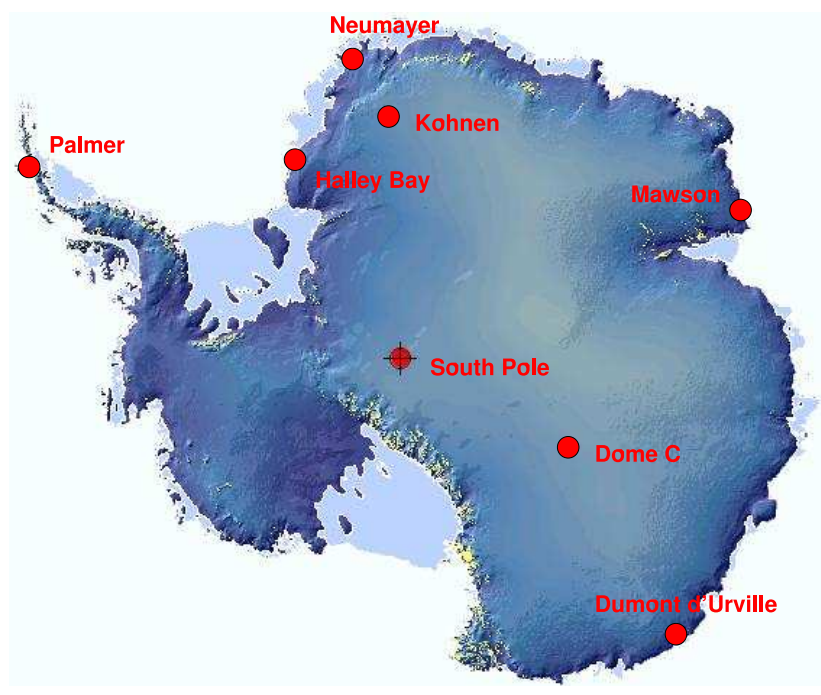

Fig. 4. Antarctic stations mentioned in this study: Dumont d'Urville $\left(140^{\circ} \mathrm{E}, 66^{\circ} 40^{\prime} \mathrm{S}\right)$, Halley Bay $\left(26^{\circ} 19^{\prime} \mathrm{W}, 75^{\circ} 35^{\prime} \mathrm{S}\right)$, Neumayer $\left(8^{\circ} 15^{\prime} \mathrm{W}, 70^{\circ} 39^{\prime} \mathrm{S}\right)$, Mawson $\left(62^{\circ} 30^{\prime} \mathrm{E}, 67^{\circ} 6^{\prime} \mathrm{S}\right)$, Palmer $\left(64^{\circ} 06^{\prime} \mathrm{W}, 64^{\circ} 77^{\prime} \mathrm{S}\right)$, Dome C $\left(123^{\circ} 21^{\prime} \mathrm{E}, 75^{\circ} 06^{\prime} \mathrm{S}\right)$, Kohnen $\left(0^{\circ} \mathrm{E}, 75^{\circ} \mathrm{S}\right)$ and South Pole $\left(0^{\circ} \mathrm{W}, 90^{\circ} \mathrm{S}\right)$.

(Dumont d'Urville, Neumayer, Halley, Mawson and Palmer, Fig. 4). Figure 5 shows the seasonal variations of simulated $\left(R_{\text {sim }}\right.$ and $R_{\text {psim }}$ ) and observed ( $\left.R_{\text {obs }}\right) R$ at these five stations. $\mathrm{R}_{\text {sim }}$ results from both the REF and $\mathrm{TESTO}_{3}$ (taking into account DMS oxidation by ozone) simulations qualitatively reproduce the most prominent feature of $R_{\text {obs }}$, that is a summer maximum and a winter minimum. In summer, DMS sources are close to Antarctic coastal stations, and the DMS oxidation channel which produces MSA with $\mathrm{OH}$ radicals is locally effective. In winter, DMS sources are far away from the coast because of sea-ice cover expansion. Furthermore, $\mathrm{OH}$ radicals are almost absent during polar night, which strongly reduces the MSA production. However, the reference simulation $\left(\mathrm{R}_{\text {sim }}\right.$, in blue) clearly under-estimates $\mathrm{R}$, especially in spring and winter, due to both an over-estimation of $\mathrm{nssSO}_{4}$ concentrations and a too weak MSA production (see also supplementary material, http://www.atmos-chem-phys. net/9/9449/2009/acp-9-9449-2009-supplement.pdf). Taking into account DMS oxidation by $\mathrm{O}_{3}\left(\mathrm{TESTO}_{3}\right.$ simulation, in red) yields almost the same results as $R_{\text {sim }}$. Indeed, although DMS oxidation by $\mathrm{O}_{3}$ allows the production of DMSO during polar night, the conversion of DMSO to MSA remains impossible in the absence of $\mathrm{OH}$.

Considering the ratio $(\mathrm{MSA}+\mathrm{DMSO}) / \mathrm{nssSO}_{4}\left(\mathrm{R}_{\mathrm{psim}}\right)$ and no reaction of DMS with ozone (blue dashed lines on Fig. 5), the seasonal variations are strongly modified compared to $\mathrm{R}_{\text {sim. }}$. The increased values of $\mathrm{R}$ are more consistent with observations at most stations, except at Palmer where it remains too weak in summer, maybe due to an inappropriate prescription of oceanic DMS oceanic concentrations and thus sources in the Antarctic Peninsula sector. $\mathrm{R}_{\mathrm{psim}}$ shows a peak in April at all sites, which is confirmed by coastal observations at Dumont d'Urville, Halley Bay, and Mawson. Although there is no perfect match between the model and the observations, this peak may coincide with the annual maximum, or be a secondary peak compared to the summer maximum (December-January). $R_{p s i m}$ also produces a secondary maximum in September (less clear at Dumont d'Urville and Halley Bay) which is not substantiated by the data (except possibly at Mawson). The higher observed values in spring than in fall may be related to a higher production of DMSO due to DMS reaction with $\mathrm{BrO}$, which is not included in the model. The spring peak being also modelled for both DMS and DMSO at coastal sites, it may be controlled by the seasonality of the prescribed marine DMS surface ocean concentrations. Finally, $\mathrm{R}_{\mathrm{psim}}$ is in far closer agreement with winter observations than $R_{\text {sim }}$. This suggests that the DMSO heterogeneous sink is also active in the absence of $\mathrm{OH}$ or that another fast DMSO to MSA conversion process takes place in winter.

Taking into account DMS oxidation by ozone as well as a fast DMSO to MSA conversion $\left(\mathrm{R}_{\mathrm{psim}}\right.$ in simulation $\mathrm{TESTO}_{3}$, red dashed lines) does not significantly modify summer values since DMS reactions with ozone are slower than oxidation by $\mathrm{OH}$. On the other hand, $\mathrm{R}_{\mathrm{psim}}$ values from simulation $\mathrm{TESTO}_{3}$ strongly over-estimate winter observations. This is due to an excessive DMSO production from DMS aqueous oxidation by $\mathrm{O}_{3}$, clearly identified between April and October. Thus, if DMS $+\mathrm{O}_{3}$ reactions have a limited impact on the seasonality of individual sulphur species (Sect. 3), the strong winter DMSO production from aqueous $\mathrm{DMS}+\mathrm{O}_{3}$ reaction combined with a fast DMSO to MSA conversion is clearly inconsistent with $R_{o b s}$. The specific polar night conditions strongly emphasize the role of ozone with respect to other oxidants. More generally, night conditions may provide interesting test cases for DMS reactions with $\mathrm{O}_{3}$.

Our model results do not take into account DMS oxidation with $\mathrm{BrO}$ which should increase $\mathrm{R}$. Measurements of MSA, $\mathrm{nssSO}_{4}, \mathrm{OH}$ and $\mathrm{BrO}$ were performed at Halley Bay in 2004 2005 (Read et al., 2007). The observed MSA/nssSO 4 ratios are somewhat higher in summer, but globally consistent with the long-term mean data plotted on Fig. 5. Read et al. (2007) calculate that a fast reaction of DMS with $\mathrm{BrO}$ could lead to DMSO concentrations more than 10 times higher than those observed at Dumont d'Urville in summer-fall. Thus, in our model, a high DMS loss due to $\mathrm{BrO}$ combined with a fast DMSO to MSA conversion would likely lead to overestimated MSA to nssSO $\mathrm{S}_{4}$ ratios. Measurements of DMSO at Halley Bay should help to solve this issue.

A similar comparison between a model and observations was carried out by Gondwe et al. (2004) at four Antarctic coastal stations. As DMSO is not explicitly calculated in their model, their results are analogs of our $\mathrm{R}_{\mathrm{psim}}$. 

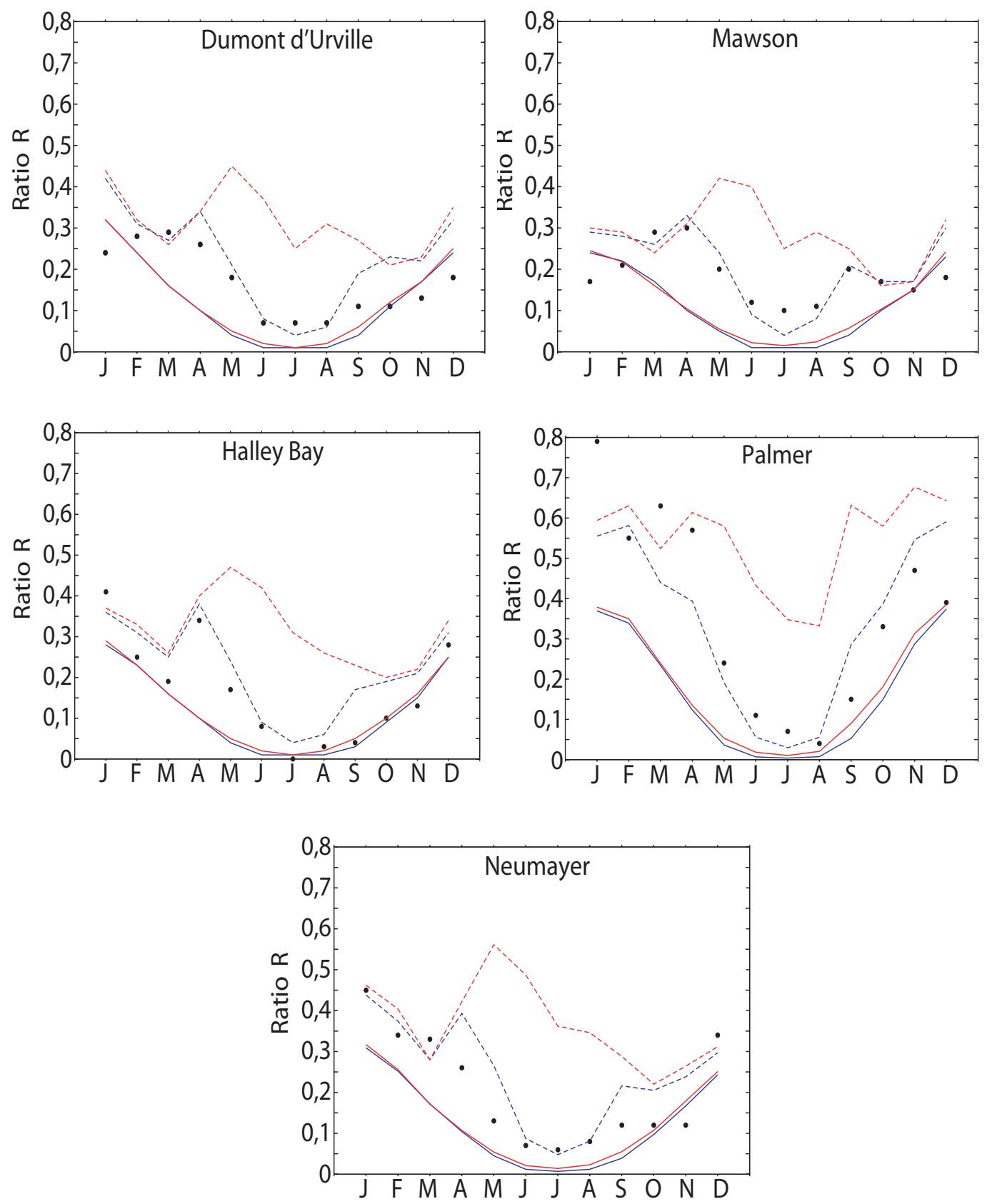

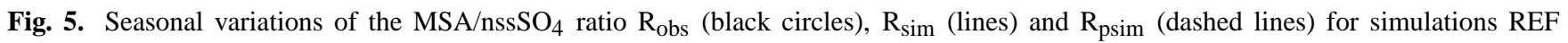
(blue) and TESTO3 (red) at five coastal Antarctic stations. Observed ratios are calculated from monthly mean concentrations of MSA and $\mathrm{nssSO}_{4}$ originating from Preunkert et al. (2007); CESOA (2007) at Dumont d'Urville for 1999-2006 period; from J. Prospero (personal communication, 2007) at Halley Bay for 1998-2002 and February 2004-January 2005; from J. Prospero (personal communication, 2007) at Mawson for 1987-1995; from R. Weller (personal communication, 2007) at Neumayer for 1983-2006; and from E. Wolff (personal communication, 2007) at Palmer for 1990-1996.

Considering all sulphur sources or only the contribution of oceanic DMS does not have a strong impact on the ratio at high-southern latitudes. Gondwe et al. (2004) obtain similar results to ours in winter, in agreement with the observations, but largely over-estimate the observations in other seasons with maxima that exceed ours. At the annual scale, their model more strongly over-predicts the $\mathrm{MSA} / \mathrm{nssSO}_{4}$ ratio in the Antarctic atmosphere (by a factor of 3-5) than our model (factor of 1.2-1.3 for $\mathrm{R}_{\mathrm{psim}}$ ). Gondwe et al. (2004) attribute this discrepancy to strong meridional variations of $\mathrm{R}$ 

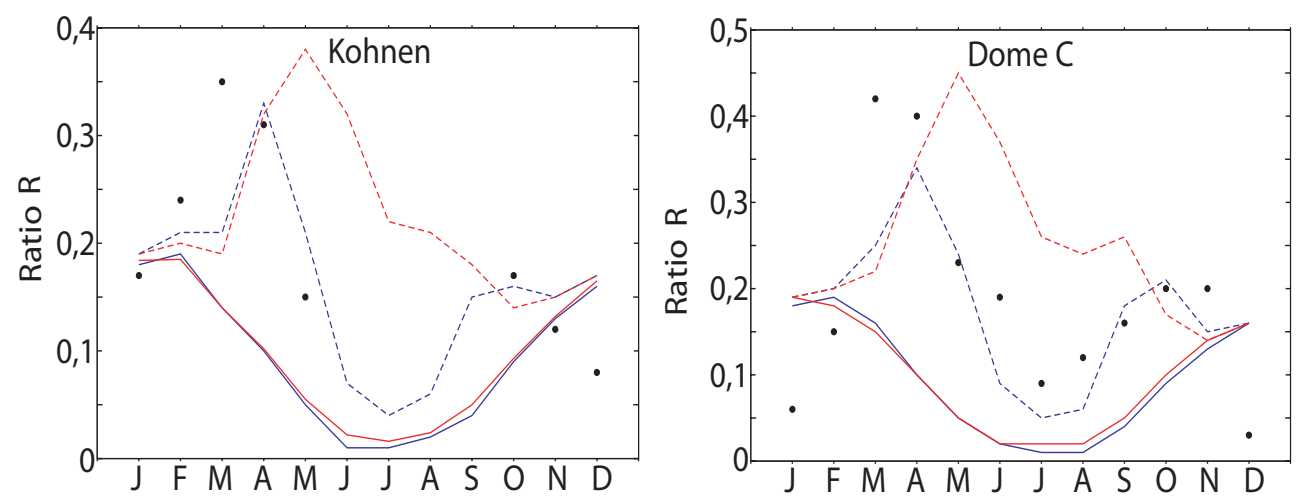

Fig. 6. Seasonal variations of the $M S A / n s s S_{4}$ ratio $R_{\text {obs }}$ (black circles), $R_{\text {sim }}$ (lines) and $R_{\text {psim }}$ (dashed lines) for simulations $R E F$ (blue) and $\mathrm{TESTO}_{3}$ (red) at 2 inland stations. Observed ratios are calculated from monthly mean concentrations of $\mathrm{MSA}$ and nssSO 4 originating from Piel et al. (2006); Weller and Wagenbach (2007) and R. Weller (personal communication, 2007) for 2003-2006 at Kohnen station and from Preunkert et al. (2008) for 2006 at Dome C station.

at the coast of Antarctica, which cannot be correctly resolved due to insufficient model grid resolution. Resolution issues are minimized in our study as we used a grid zoomed over Antarctica.

\subsection{Antarctic continent interior}

Most simultaneous atmospheric MSA and $\mathrm{nssSO}_{4}$ observations at inland Antarctic sites cover only the summer period (de Mora et al., 1997; Arimoto et al., 2001, 2004; Udisti et al., 2004a; Piel et al., 2006; Arimoto et al., 2008, i.e. November to January). They indicate MSA levels lower than $\mathrm{nssSO}_{4}$, resulting in $\mathrm{R}$ values ranging from 0.03 to 0.20 . The two year-round studies of sulphur aerosols recently conducted over inland Antarctica (Weller and Wagenbach, 2007; Preunkert et al., 2008) at Kohnen and Dome C stations reveal a seasonality with low $\mathrm{R}$ values in December-January in contrast with higher levels measured in fall and spring (Fig. 6). The major difference between the coastal and inland records of $\mathrm{R}$ is the low summer values inside the continent (in December at Kohnen and in December-January at Dome C). In winter, $\mathrm{R}$ decreases at Dome C, whereas it cannot be evaluated at Kohnen station because MSA measurements were below the detection limit (Weller and Wagenbach, 2007). Using the detection limit value (2.6 pptv), the upper limit for $\mathrm{R}$ is 0.27 .

$\mathrm{R}_{\text {sim }}$ results of simulations REF and $\mathrm{TESTO}_{3}$ are similar and, as for coastal sites, fall short of reproducing the observed seasonal variations of $\mathrm{R}$. However, assuming a fast DMSO to MSA conversion $\left(\mathrm{R}_{\mathrm{psim}}\right)$ for the reference simulation (blue dashed lines in Fig. 6) strongly improves the agreement with the observation although an over-estimation of summer values at Dome $\mathrm{C}$ remains. This over-estimation is the result of the over-estimated sulphur aerosol levels (Fig. 3) and the model inability to reproduce the reduced MSA observed between December and February. As only one year of data is available for Dome $\mathrm{C}$, the inter-annual variability is not represented, resulting in an unknown uncertainty on results. Indeed, Arimoto et al. (2008) observed substantial year-to-year variations of $\mathrm{R}$ in summer at South Pole. However, only their highest values are consistent with our model results. Taking into account additional oxidation processes by ozone (red dashed lines) has only a small effect on model results in summer as DMS is completely oxidized before reaching inland stations. Using back trajectory analysis, Arimoto et al. (2008) and Preunkert et al. (2008) both suggest that the lowest summer values of $\mathrm{R}$ are associated with air masses which have spent a long time over the continent. Thus, the model over-estimation of $\mathrm{R}$ could be due, at least in part, (1) to the fast modelled transport over Antarctica (see Sect. 4.4) and (2) to the low deposition velocities of sulphur aerosols, prescribed in the model as equivalent for MSA and $\mathrm{nssSO}_{4}$. The model indicates a peak in April for all stations (inland and coastal), whereas observations show similar values in March and April. This is linked to the fact that sulphur aerosols are sensitive to the DMS sources in the model, even over the Antarctic plateau due to an effective transport (as discussed in Sect. 3.2). Taking into account both a fast conversion of DMSO into MSA and the DMS oxidation by ozone $\left(\mathrm{R}_{\mathrm{psim}}\right.$ for simulation $\left.\mathrm{TESTO}_{3}\right)$ lead to strongly overestimated values of $\mathrm{R}$ in winter in central Antarctica, as for coastal stations.

\subsection{Mid-southern latitude sites}

Mean seasonal variations of $\mathrm{R}$ at Cape Grim $\left(144^{\circ} \mathrm{E}\right.$, $\left.40^{\circ} \mathrm{S}\right)$ and Amsterdam Island $\left(77^{\circ} \mathrm{E}, 37^{\circ} 50 \mathrm{~S}\right)$ are depicted on Fig. 7. The model reproduces the observed seasonality, with a minimum in winter and a maximum in summer. However, at both sites, the model simulates a primary maximum in January while observations indicate a maximum in February. The model clearly 

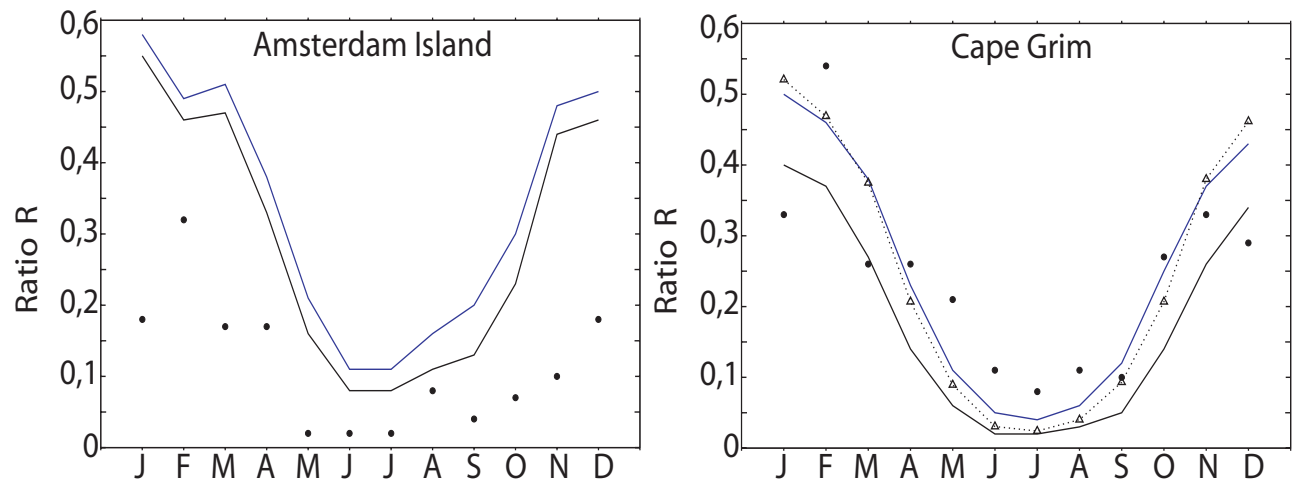

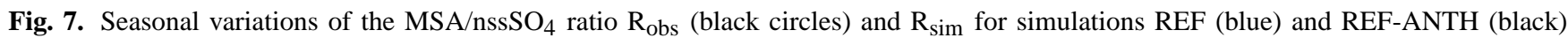
at 2 mid-southern latitude stations. Black triangles represent $\mathrm{R}_{\text {sim }}$ from simulation REF-ANTH at an oceanic grid-point slightly south of Cape Grim. Observed ratios are calculated from monthly mean concentrations of $\mathrm{MSA}$ and nssSO 4 originating from CESOA (2007) for 2003-2006 at Amsterdam Island and from M. Keywood (personal communication, 2007) for 1988-2006 at Cape Grim.

over-estimates R observations at Amsterdam Island, and taking into account anthropogenic sources (simulation REFANTH in black) is insufficient to correct this feature. This is mostly due to the over-estimation of MSA concentrations (Fig. 2). However, we should remember the high variability in $\mathrm{nssSO}_{4}$ data (Sect. 3.2) which affects the observed values of $\mathrm{R}$. The model fairly well reproduces observations at Cape Grim in spite of an under-estimation in fall-winter. However, as the model strongly over-estimates both MSA and $\mathrm{nssSO}_{4}$ levels at this station (see supplementary material, http://www.atmos-chem-phys.net/9/9449/ 2009/acp-9-9449-2009-supplement.pdf), the agreement for $\mathrm{R}$ could be somewhat fortuitous. As this site is subject to several influences (marine, anthropogenic, biomass burning), specific sensitivity test were performed. If anthropogenic sources are included (simulation REF-ANTH in black), R decreases year-round due to higher amounts of $\mathrm{nssSO}_{4}$ worsening the under-estimation at Cape Grim during winter. The available observations at Cape Grim were made representative of ocean conditions by selecting data depending on wind direction (oceanic sector) and number of condensation nuclei (Ayers et al., 1991; Ayers and Gillett, 2000). Such conditions only occur during $30 \%$ of the time. To tentatively reproduce the experimental sectorial selection, $\mathrm{R}_{\text {sim }}$ was extracted from simulation REF-ANTH at an oceanic point south of Cape Grim $\left(144^{\circ} \mathrm{E}, 45^{\circ} \mathrm{S}\right)$. The results (black triangles in Fig. 7) are in better agreement with observations, showing that this site may be sensitive to model grid resolution. The oceanic influence is then amplified and anthropogenic sources influence is conversely reduced. A strongly reduced impact of anthropogenic sources is obtained in summer whereas this effect is weaker in winter.

\section{Meridional variations of the $\mathrm{MSA}$ to $\mathrm{nssSO}_{4}$ ratio}

\subsection{Spatial variation between year-round measurement stations}

As a first approach to tentatively address the model ability to represent the spatial variations of $\mathrm{R}$, model results are compared with atmospheric data from Antarctic and subAntarctic stations (Table 2). We showed previously that a fast DMSO to MSA conversion ( $\left.\mathrm{R}_{\mathrm{psim}}\right)$ probably corrects for a missing oxidation process in the model and thus improves the agreement with observations. Besides, implementing DMS oxidation by ozone does not improve model results, whereas the addition of anthropogenic sulphur sources affect only mid-latitude sites (see Sect. 4.3). Thus, Table 2 only reports $\mathrm{R}_{\mathrm{psim}}$ results from simulation REF-ANTH. Although the model somewhat over-estimates $\mathrm{R}$ at mid-latitudes, it fairly well reproduces $\mathrm{R}$ at coastal Antarctic stations. Inside the continent, winter values are correctly represented whereas summer values are over-estimated (see Sect. 4.2). Model results suggest a meridional gradient of the ratio $\mathrm{R}$ from mid-latitudes to the Antartic plateau. This gradient is weaker in winter than in summer (or for the whole year). On the other side, no clear gradient can be seen in the observations which are dominated by site-to-site variability, except between coastal Antarctica and the central plateau in summer. This contrasted seasonal behaviour is confirmed by measurements made in 2006 at both Dumont d'Urville and Dome C stations (Preunkert et al., 2008). The summer gradient has been linked to a faster decrease of MSA than nssSO $_{4}$ (e.g. Kärkäs et al., 2005; Arimoto et al., 2008) which is reproduced with an insufficient amplitude by the model. At the global scale, Gondwe et al. (2004) compiled a large number of data and concluded that the ratio $\mathrm{R}$ is highest in polar regions and lowest within the tropics. However, 


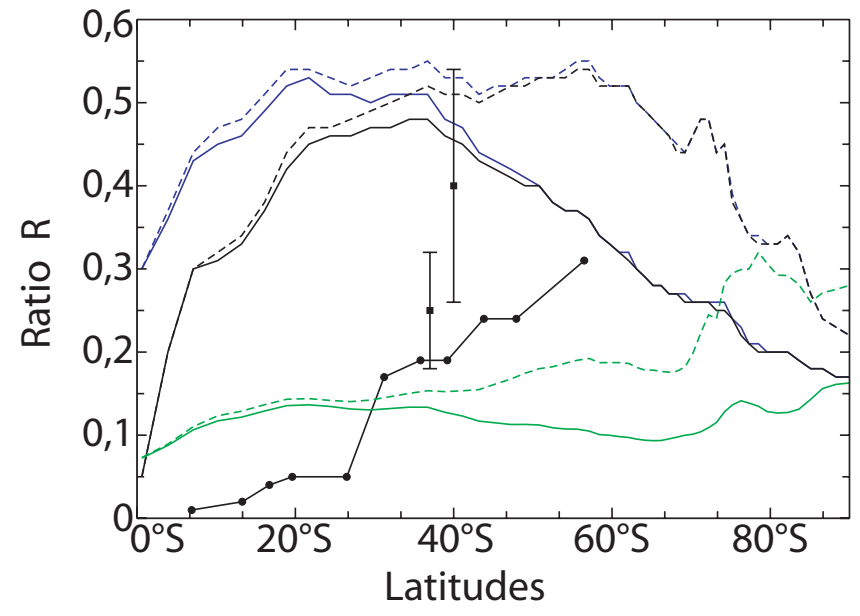

Fig. 8. MSA to $\mathrm{nssSO}_{4}$ ratio in the South Pacific Ocean. Modelled $\mathrm{R}_{\text {sim }}$ and $\mathrm{R}_{\text {psim }}$ are represented by solid and dashed lines respectively. Simulations results are represented in blue for REF, in black for REF-ANTH and in green for the simulation using the previous chemistry scheme (Cosme et al., 2002). Modelled R are averaged between 105 and $110^{\circ} \mathrm{W}$, in February/March, in order to be compared with measurements from (Bates et al., 1992) (solid line with circles). Data from Cape Grim and Amsterdam Island are also shown as black squares (February/March averages, see Fig. 7 for data sources).

complete seasonal cycles are rarely available and more continuous measurements are necessary for a confident assessment.

\subsection{Meridional variations over mid and high-southern latitudes}

Sulphur species measurements were performed by Bates et al. (1992) in February-March 1989, in the South Pacific Ocean, along a meridian transect from $6.9^{\circ} \mathrm{S}$ to $56.5^{\circ} \mathrm{S}$ in the narrow longitude band from 105 to $110^{\circ} \mathrm{W}$. These authors observed a strong anti-correlation of $\mathrm{R}$ with temperature, related to its increase with latitude. However, individual species (DMS and its oxidation products) showed a more complex behaviour. The meridional increase in $\mathrm{R}$ observed by Bates et al. (1992) contrasts with the sub-Antarctic and Antarctic station data (Sect. 5.1 and Table 2). Amsterdam Island and Cape Grim data show higher values of $\mathrm{R}$ than those observed by Bates et al. (1992) around $40^{\circ} \mathrm{S}$ : whereas Bates et al. (1992) measured a ratio about 0.2 in FebruaryMarch, autumn averages of $0.25( \pm 0.07)$ and $0.40( \pm 0.14)$ are measured at Amsterdam Island and Cape Grim respectively. Thus, at a given latitude in the Southern Ocean, $R$ may undergo important short term and/or zonal variations.

Figure 8 presents results from simulations REF and REFANTH (in blue and black respectively), as well as a simulation taking into account our previous chemistry module
Table 3. $\mathrm{R}$ in Antarctic snow from firn and ice cores collected at various sites, compared with model results (simulation REF) calculated from deposition fluxes of MSA and $\mathrm{nsSSO}_{4}$. References for the data: Minikin et al. $(1998)^{\mathrm{a}}$, Legrand et al. (1992) ${ }^{\mathrm{b}}$, Legrand and Pasteur $(1998)^{\mathrm{c}}$, and Udisti et al. $(2004 \mathrm{~b})^{\mathrm{d}}$.

\begin{tabular}{lcrcc}
\hline Sites & Site category & $\mathrm{R}_{\text {obs }}$ & $\mathrm{R}_{\text {sim }}$ & $\mathrm{R}_{\text {psim }}$ \\
\hline Ekstrom 040 & Ice Shelf & $0.11^{\mathrm{a}}$ & 0.20 & 0.29 \\
Ekstrom 070W & Ice Shelf & $0.10^{\mathrm{a}}$ & 0.19 & 0.27 \\
Ekstrom 090 & Ice Shelf & $0.05^{\mathrm{a}}$ & 0.19 & 0.27 \\
FRIS 131 & Ice Shelf & $0.20^{\mathrm{a}}$ & 0.22 & 0.31 \\
FRIS 136 & Ice Shelf & $0.16^{\mathrm{a}}$ & 0.22 & 0.29 \\
FRIS 230 & Ice Shelf & $0.20^{\mathrm{a}}$ & 0.21 & 0.29 \\
FRIS 235 & Ice Shelf & $0.19^{\mathrm{a}}$ & 0.22 & 0.29 \\
FRIS 240 & Ice Shelf & $0.23^{\mathrm{a}}$ & 0.22 & 0.29 \\
FRIS 231 & Ice Shelf & $0.26^{\mathrm{a}}$ & 0.21 & 0.29 \\
FRIS 236 & Ice Shelf & $0.20^{\mathrm{a}}$ & 0.21 & 0.29 \\
FRIS 330 & Ice Shelf & $0.14^{\mathrm{a}}$ & 0.21 & 0.27 \\
FRIS 335 & Ice Shelf & $0.19^{\mathrm{a}}$ & 0.21 & 0.27 \\
FRIS 340 & Ice Shelf & $0.16^{\mathrm{a}}$ & 0.21 & 0.27 \\
FRIS 336 & Ice Shelf & $0.15^{\mathrm{a}}$ & 0.21 & 0.27 \\
FRIS 341 & Ice Shelf & $0.12^{\mathrm{a}}$ & 0.21 & 0.27 \\
FRIS BAS Site 5 & Ice Shelf & $0.07^{\mathrm{a}}$ & 0.20 & 0.26 \\
FRIS BAS Site 6 & Ice Shelf & $0.09^{\mathrm{a}}$ & 0.20 & 0.24 \\
& & & & \\
Dolleman Island & Coastal & $0.39^{\mathrm{a}}$ & 0.24 & 0.33 \\
Berkner N & Coastal & $0.17^{\mathrm{a}}$ & 0.22 & 0.31 \\
Berkner S & Coastal & $0.20^{\mathrm{a}}$ & 0.22 & 0.30 \\
Gomez Nutanak & Coastal & $0.32^{\mathrm{a}}$ & 0.22 & 0.34 \\
Law Dome & Coastal & $0.18^{\mathrm{a}}$ & 0.21 & 0.33 \\
Byrd & Interior & $0.18^{\mathrm{a}}$ & 0.15 & 0.20 \\
South Pole & Interior & $0.12^{\mathrm{a}}$ & 0.13 & 0.13 \\
& & $0.13(\mathrm{January})^{\mathrm{b}}$ & 0.18 & 0.18 \\
Dome C - 1978 & Interior & 0.18 Winter $^{\mathrm{c}}$ & 0.02 & 0.02 \\
Vostok & Interior & $0.03^{\mathrm{a}}$ & 0.12 & 0.12 \\
Dome C - EPICA & Interior & $0.02^{\mathrm{a}}$ & 0.12 & 0.12 \\
\hline
\end{tabular}

(Cosme et al. (2002), in green). Model results are highly dependent on the model version used. Sensitivity tests showed that this is not related with the change in model dynamics (version 3 to version 4, not shown here) but to the update of the DMS chemistry scheme. It should be reminded that DMSO reaction with $\mathrm{OH}$ provides the only pathway to MSA in our chemistry scheme (via MSIA) and that the endproducts of MSIA reaction with $\mathrm{OH}$ are still poorly known (see Sect. 3.1). The increased temperature dependence of chemical reactions rates and branching ratios (especially $\mathrm{k} 2$ and $\mathrm{k} 6$ in Table 1) leads to larger variations of $R_{\text {sim }}$ and $R_{p s i m}$ with latitude. The results from our two model versions (green and blue lines) bracket the data in the extra-tropical southern latitudes, whereas all model results over-estimate the measurements in the tropics. This may be related to the lower meridional resolution of our model at low latitudes due to its grid zoomed over Antarctica. On the other hand, back trajectory analysis performed by Bates et al. (1992) suggest that the data collected north of $30^{\circ} \mathrm{S}$ may be more influenced by south-American anthropogenic sulphur sources than data collected further south. 
The updated model results $\left(\mathrm{R}_{\mathrm{sim}}\right.$, simulation $\mathrm{REF}$ in blue) exhibit two main features: (1) a meridional increase between 0 and $35^{\circ} \mathrm{S}$ and (2) a decrease south of $40^{\circ} \mathrm{S}$. The modelled meridional increase of $\mathrm{R}$ between 0 and $35^{\circ} \mathrm{S}$ is in qualitative agreement with observations from Bates et al. (1992). Taking into account anthropogenic sulphur sources (REF-ANTH simulation, black lines) reduces R north of $50^{\circ} \mathrm{S}$, but still over-estimates the observations. The modelled meridional increase is related to the temperature dependence of MSA production: a lower temperature favours the addition channel of DMS oxidation by $\mathrm{OH}$ producing MSA. At higher latitudes, REF and REF-ANTH simulations yield the same results: the anthropogenic sources have no significant impact, confirming Cosme et al. (2005) results. On the other hand, model results become sensitive to a fast conversion of DMSO into MSA. The updated model (REF and REF-ANTH) exhibits a gradual decrease of $\mathrm{R}_{\text {sim }}$ and $\mathrm{R}_{\text {psim }}$ between $60^{\circ} \mathrm{S}$ and South Pole, in qualitative agreement with the summer coastal-inland gradient over Antarctica discussed in Sect. 5.1. This is due to the temperature-dependent reaction products of MSIA reaction with $\mathrm{OH}$ in the new chemistry scheme: MSA production decreases when temperature cools and only $\mathrm{SO}_{2}$ is formed below $-32^{\circ} \mathrm{C}$. The modelled annual and zonal mean variations of $\mathrm{R}$ with latitude (see supplementary material, http://www.atmos-chem-phys. net/9/9449/2009/acp-9-9449-2009-supplement.pdf) are similar to the results plotted on Fig. 8 (105-140 ${ }^{\circ} \mathrm{W}$, FebruaryMarch). Maximum values of $\mathrm{R}$ are displaced southward $\left(\sim 60^{\circ} \mathrm{S}\right)$, and the impact of anthropogenic sources reaches higher latitudes (up to $\sim 50^{\circ} \mathrm{S}$ ). Overall, meridional variations of $\mathrm{R}$ show a complex behaviour which cannot be easily related to either temperature or anthropogenic emissions only, as previously assumed (see Sect. 1). Model results are highly dependent on temperature dependence and branching ratios of reaction rates in the DMS oxidation scheme, which are still incompletely known.

\section{Variations of the MSA to nssSO $_{4}$ ratio in snow/ice}

In several instances, the LMD-ZT Antarctic-refined model has been used to simulate and interpret glacial climate (e.g. Krinner and Genthon, 1998). Coupled with the sulphur chemistry module, it also permitted to simulate the sulphur cycle at the Last Glacial Maximum, 21000 years ago (Castebrunet et al., 2006) and was thus evaluated against ice core records of $\mathrm{MSA}$ and $\mathrm{nssSO}_{4}$. In a paleo-climate context, it has been suggested that the ratio $\mathrm{R} \mathrm{MSA} / \mathrm{nssSO}_{4}$ could allow to determine the latitude of DMS emissions which produced the MSA and $\mathrm{nssSO}_{4}$ measured in Antarctic ice cores (Legrand et al., 1992). The assessment of the representation of $\mathrm{R}$ in snow and ice by our model is thus required for a better understanding of the relation between the sulphur cycle and climate changes.
Table 3 presents a compilation of $\mathrm{R}$ values calculated from measured deposition fluxes of MSA and $\mathrm{nssSO}_{4}$ in firn and ice cores. Most data were compiled by Minikin et al. (1998) at 26 Antarctic sites, we added data from Udisti et al. (2004b) at Dome C (EPICA ice core) and Legrand et al. (1992); Legrand and Pasteur (1998) at South Pole station. Most measurement sites are located on ice-shelves in the west of the continent, especially in the Weddell sector. No data is available between 0 and $90^{\circ} \mathrm{E}$. To tentatively address the model ability to represent the spatial variability of $\mathrm{R}$ in snow, these measurements are compared with model results $\left(R_{\text {sim }}\right.$ and $\mathrm{R}_{\mathrm{psim}}$ from simulation $\mathrm{REF}$ ). Modelled ratios are calculated from deposition fluxes of $\mathrm{MSA}, \mathrm{nssSO}_{4}$ and DMSO together with snow accumulation rate. We should note that as DMSO undergoes weaker deposition processes than MSA (no below-cloud deposition, no dry deposition on ice), $\mathrm{R}_{\mathrm{psim}}$ in snow does not fully represent the effect of a fast conversion of DMSO into MSA. The model somewhat over-estimates R on ice-shelves (by $60 \%$ on the average). A fast conversion of DMSO into MSA $\left(\mathrm{R}_{\mathrm{psim}}\right)$ increases this over-estimation (110\% mean difference). The lowest values of the observed range (between 0.07 and 0.26 ) are not well represented by the model ( 0.19 to 0.22 for $R_{\text {sim }}$, and 0.24 to 0.29 for $\left.R_{p s i m}\right)$. The model resolution is too low to reproduce the small-scale spatial variability between these seventeen sites. At the five coastal sites, measurements provide ratios ranging between 0.18 and 0.39 . The model $\left(\mathrm{R}_{\text {sim }}\right)$ simulates correctly the average ratio ( $2.5 \%$ under-estimation) but under-estimates again data variability (model range: $0.21-0.24$ ). As for ice-shelf sites, taking into account $\mathrm{R}_{\mathrm{psim}}$ deteriorates the representation of $\mathrm{R}$ in snow. This behaviour contrasts with the atmospheric ratio (see Sect. 4.1). Over central Antarctica, lower ratios are observed, especially on the Eastern plateau. The model also produces lower values, but if the annual averages are well represented at Byrd and South Pole, they are strongly over-estimated at Vostok and Dome $\mathrm{C}$. $\mathrm{R}_{\mathrm{psim}}$ equals $\mathrm{R}_{\text {sim }}$ at central plateau stations: dry deposition is dominant at these low accumulation-rate sites (e.g. Wolff et al., 2006), thus $\mathrm{R}_{\mathrm{psim}}$ in snow does not correctly represent a fast DMSO to MSA conversion. At South Pole, measurements in snow deposited in January lead to a $\mathrm{R}$ value of about 0.13 (Legrand et al., 1992), twice as large as atmospheric values (about 0.06) (Arimoto et al., 2001, 2008). The model provides a ratio in snow of 0.18 , identical to its atmospheric value. For winter snow/firn, Legrand and Pasteur (1998) measured a ratio of about 0.18 whereas the model leads to a value of 0.021 . This value is similar to $\mathrm{R}_{\text {sim }}$ in the atmosphere, but as DMSO undergoes no dry deposition on snow, $\mathrm{R}_{\text {psim }}$ in snow does not compensate for the missing MSA. Similarly, although the model reproduces quite well the atmospheric ratios at Dome $\mathrm{C}$ and Kohnen stations between April and November, it strongly under-estimates observed data in snow/firn. The atmosphere to snow transfer is governed by deposition fluxes of MSA and nssSO 4 . No direct measurements of the dry deposition velocities on snow are available for sulphur aerosols. 

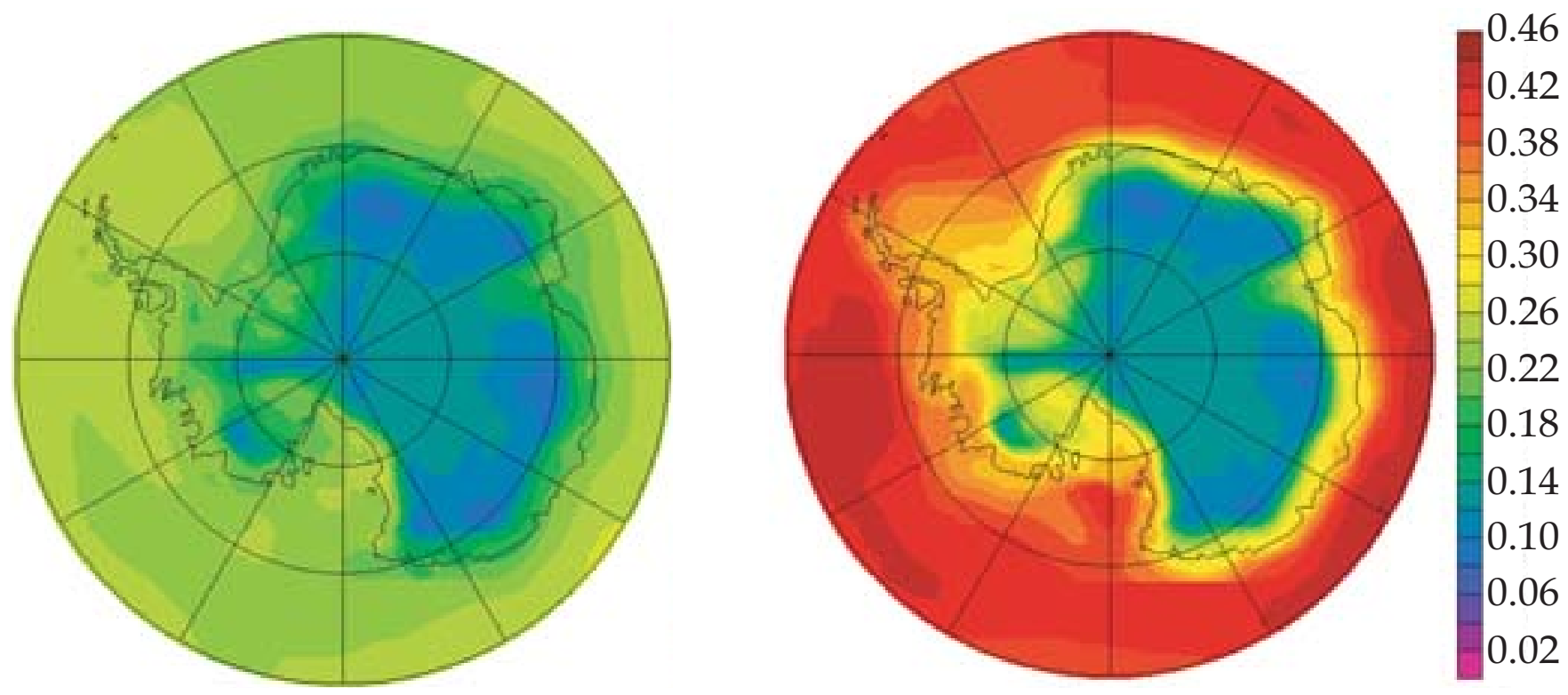

Fig. 9. $\mathrm{MSA} / \mathrm{nssSO}_{4}$ ratio R calculated from modelled deposition fluxes of $\mathrm{MSA}, \mathrm{nssSO}_{4}$ and $\mathrm{DMSO}$. Left panel: $\mathrm{MSA}_{\mathrm{nssSO}} \mathrm{ratio}_{\mathrm{sim}}$. Right panel: (MSA+DMSO)/nssSO 4 ratio $\mathrm{R}_{\mathrm{psim}}$.

Our model values were adjusted to fit the overall sulphate deposition fluxes over Antarctica (Castebrunet, 2007) and identical dry deposition velocities were adopted for $\mathrm{nssSO}_{4}$ and MSA. A seasonal bias, as well as the under-estimated spatial variations of $\mathrm{R}$ are thus not surprising. Besides, several experimental studies suggest that MSA concentrations in snow/ice at sites characterized by low snow accumulation rates are influenced by reversible deposition (Wagnon et al., 1999; Delmas et al., 2003), migration through firn layers (Mulvaney et al., 1992; Pasteur and Mulvaney, 2000) and/or MSA redistribution by wind (Wolff et al., 1998). Simultaneous measurements of sulphur aerosols in the atmosphere and snow at several Antarctic stations would be necessary to better understand these processes and improve the model parameterization.

Despite the above mentioned biases, a clear coast to inland gradient, substantiated by the data, is produced by the model over the Antarctic continent. Figure 9 presents geographical maps of the modelled ratios $R_{\text {sim }}$ and $R_{\text {psim }}$ in snow. Higher $\mathrm{R}_{\text {sim }}$ values are obtained in coastal regions $(0.20-0.26)$ than on the central plateau $(0.04-0.14)$. As seen previously, a fast conversion of DMSO into MSA ( $\left.\mathrm{R}_{\mathrm{psim}}\right)$ increases $\mathrm{R}$ above the Southern Ocean and coastal regions (0.26-0.34) but brings little change inland. Data from Table 3 show a mean ratio $\mathrm{R}$ (ice-shelves and coastal)/R(inland) of 2.2, whereas model results at the same sites $\left(\mathrm{R}_{\text {sim }}\right)$ leads to a smaller change (1.65). Kärkäs et al. (2005) also observed a faster decrease for MSA than $\mathrm{nsSSO}_{4}$ in snow samples from a $350 \mathrm{~km}$ coast to inland transect in Dronning Maud Land (these data were not reported in Table 3 because they cover only a small summer fraction of the annual snow accumulation). These spatial variations were previously explained by (1) a shorter atmospheric lifetime of MSA with respect to nssSO $_{4}$ due to a larger size of MSA aerosols and a faster dry deposition, but this explanation is being questioned by sizesegregated aerosol composition data at Dumont d'Urville and Dome C (Jourdain and Legrand, 2001; Jourdain et al., 2008), and (2) a possible post-depositional loss of MSA as already mentioned. The modelled spatial variations of $\mathrm{R}$ cannot be due to different deposition velocities for MSA and $\mathrm{nssSO}_{4}$ or post-depositional effects, as these processes are not represented in the model. Thus we suggest that atmospheric chemistry and transport processes play an important role on the spatial distribution of $\mathrm{R}$ in Antarctic snow.

\section{Conclusions}

Large uncertainties remain on the natural sulphur cycle due to sparse observational data and the still recent and incomplete development of 3-D model studies focussed on the southern hemisphere. This work aimed at better understanding the processes which influence seasonal and spatial variations of the MSA to nssSO 4 ratio (R) in air and snow at mid and high-southern latitudes. Although the model overestimates MSA and $\mathrm{nsSSO}_{4}$ concentrations at mid-latitude and inland Antarctic sites, it is more successful in simulating R. Biases in DMS emission fluxes and transport have somewhat similar effects on MSA and $\mathrm{nsSSO}_{4}$ concentrations, and likely affect less their concentration ratio. In the studied regions, where marine emissions dominate the anthropogenic 
contribution to sulphate, this may also explain why $\mathrm{R}$ is more sensitive to chemical processes in the DMS oxidation scheme than sulphur species concentrations.

The model successfully simulates seasonal variations of $R$ in the Antarctic atmosphere if a fast conversion process of DMSO into MSA is taken into account. The importance of such a conversion has been highlighted by several authors for the summer season (Ravishankara et al., 1997; Davis et al., 1998; Sciare et al., 2000; Legrand et al., 2001), whereas our results suggest that its effects on $\mathrm{R}$ could be highest in fall and spring, and persist in winter. On the other hand, taking into account DMS oxidation by ozone leads to highly overestimated values of $\mathrm{R}$ in winter, due to the aqueous phase reaction, suggesting an insufficient knowledge of this reaction speed. Field campaigns involving detailed sulphur speciation and oxidant measurements, which have been performed in summer (e.g. Davis et al., 1998), would have to be extended to other seasons in order to directly test the effect of these processes. Simultaneous observations of DMS, BrO and DMSO would better constrain the role of $\mathrm{BrO}$ in DMS oxidation.

The MSA to nssSO 4 ratio in Antarctic snow is also fairly well simulated except at the most inland sites undergoing very low accumulation rates. A significant coastal to inland decrease in R is obtained although the modelled MSA and $\mathrm{nssSO}_{4}$ dry deposition velocities are identical, and no postdepositional processes are taken into account for MSA. This suggests that an important part of the observed decrease can be explained by atmospheric processes. Simultaneous measurements of MSA and sulphate in the atmosphere and snow would be especially helpful to better understand and parameterize their deposition velocities, and thus better simulate their present spatial distribution in snow and their ice core records.

The modelled large-scale meridional variations of $\mathrm{R}$ in the atmosphere are highly sensitive to the chemistry scheme used, especially the temperature dependence of the branching ratio between abstraction and addition of the DMS reaction with $\mathrm{OH}$ (which has been recently re-evaluated) and the end products of the MSIA reaction with $\mathrm{OH}$, which are still poorly known. Improved kinetic data are thus necessary to better constrain the atmospheric DMS oxidation scheme, especially for the MSIA+OH reaction products. On the other hand, the MSA to nssSO ${ }_{4}$ ratio in the south hemisphere behaves as a sensitive diagnostics to test chemical mechanisms.

Observational data qualitatively support the modelled "bell shape" of R meridional variations, with a southward increase at mid-latitudes and a decrease over Antarctica. This complex behaviour cannot be explained by a direct relationship between $\mathrm{R}$ and either temperature or anthropogenic emissions only, as previously suggested.

Overall, this study suggests that the MSA to nssSO ${ }_{4}$ ratio at mid and high-southern latitudes is mainly dependent on DMS oxidation pathways. Its seasonal and meridional variations in the atmosphere appear related to the availabil- ity of different oxidants and the temperature dependence of chemical reaction rates and branching ratios. Understanding the MSA to $\mathrm{nssSO}_{4}$ ratio in Antarctic snow is important for ice core interpretation. A large discrepancy (about a factor 10) between model results and measurements in snow is obtained only at the lowest accumulation rate sites in winter. With this exception, our results indicate that atmospheric chemistry and transport are responsible for a significant part of the spatial distribution of $\mathrm{R}$ in Antarctic snow.

Acknowledgements. This work was supported by Institut National des Sciences de l'Univers (INSU), program LEFE/CHAT. It benifited from observations of the CESOA program, available at http://cesoa.ore.fr. Other data where kindly provided by E. Wolff (British Antarctic Survey), R. Weller (Alfred Wegener Institute), J. M. Prospero (University of Miami) and M. Keywood (Australian Commonwealth Scientific and Research Organization). The page charges for this article were covered by the contract between Copernicus and INSU, component of Centre National de la Recherche Scientifique (CNRS).

Edited by: N. Mihalopoulos

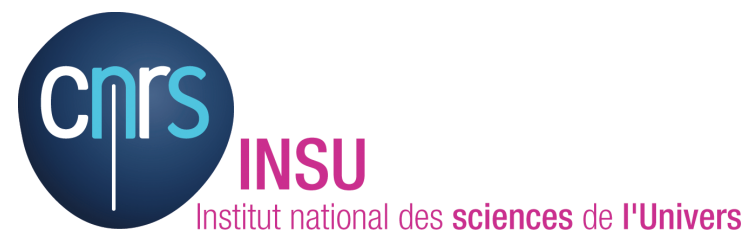

The publication of this article is financed by CNRS-INSU.

\section{References}

Albu, M., Barnes, I., Becker, K. H., Patroescu-Klotz, I., Mocanu, R., and Benter, T.: Rate coefficients for the gas-phase reaction of $\mathrm{OH}$ radicals with dimethyl sulfide: temperature and $\mathrm{O}_{2}$ partial pressure dependence, Phys. Chem. Chem. Phys., 8, 728-736, doi:10.1039/b512536g, 2006.

Arimoto, R., Nottingham, A. S., Webb, J., Schloesslin, C. A., and Davis, D. D.: Non-sea salt sulfate and other aerosol constituents at the South Pole during ISCAT, Geophys. Res. Lett., 28, 3645-3648, doi:10.1029/2000GL012714, 2001.

Arimoto, R., Zhang, X., Huebert, B., Kang, C., Savoie, D., Prospero, J., Sage, S., Schloesslin, C., Khaing, H., and Oh, S.: Chemical composition of atmospheric aerosols from Zhenbeitai, People's Republic of China, and Gosan, South Korea, during ACE-Asia, J. Geophys. Res., 109, D19S04, doi:10.1029/2003JD004323, 2004.

Arimoto, R., Zeng, T., Davis, D., Wang, Y., Khaing, H., Nesbit, C., and Huey, G.: Concentrations and sources of aerosol ions and trace elements during ANTCI-2003, Atmos. Environ., 42, 28642876, doi:10.1016/j.atmosenv.2007.05.054, 2008.

Arsene, C., Barnes, I., and Becker, K. H.: FT-IR product study of the photo-oxidation of dimethyl sulfide: Temperature and $\mathrm{O}_{2}$ partial pressure dependence, Phys. Chem. Chem. Phys., 1, 54635470, doi:10.1039/a907211j, 1999.

Arsene, C., Barnes, I., Becker, K. H., Schneider, W. F., Wallington, T. T., Mihalopoulos, N., and Patroescu-Klotz, I. V.: Formation of 
methane sulfinic acid in the gas-phase $\mathrm{OH}$-radical initiated oxidation of dimethyl sulfoxide, Environ. Sci. Technol., 36, 51555163, doi:10.1021/es020035u, 2002.

Atkinson, R., Cox, R. A., Crowley, J. N., Hampson Jr, R. F., Hynes, R. G., Jenkin, M. E., Kerr, J. A., Rossi, M. J., and Troe, J.: Summary of evaluated kinetic and photochemical data for atmospheric chemistry - Section $\mathrm{I}-\mathrm{O}_{\mathrm{x}}, \mathrm{HO}_{\mathrm{x}}, \mathrm{NO}_{\mathrm{x}}$ and $\mathrm{SO}_{\mathrm{x}}$ reactions, http://www.iupac-kinetic.ch.cam.ac.uk/, last access: June 2007, 2006.

Ayers, G. P. and Gillett, R. W.: DMS and its oxidation products in the remote marine atmosphere: implications for climate and atmospheric chemistry, J. Sea Res., 43, 275-286, doi:10.1016/ S1385-1101(00)00022-8, 2000.

Ayers, G. P., Ivey, J. P., and Gillett, R. W.: Coherence between seasonal cycles of dimethylsulphide, methanesulphonate and sulphate in marine air, Nature, 349, 404-406, 1991.

Ayers, G. P., Cainey, J. M., Granek, H., and Leck, C.: Dimethylsulfide oxidation and the ratio of methanesulfonate to non seasalt sulfate in the marine aerosol, J. Atmos. Chem., 25, 307-325, 1996.

Bardouki, H., Barcellos da Rosa, M., Mihalopoulos, N., Palm, W.U., and Zetzsch, C.: Kinetics and mechanism of the oxidation of dimethylsulfoxide (DMSO) and methanesulfinate $\left(\mathrm{MSI}^{-}\right)$by $\mathrm{OH}$ radicals in aqueous medium, Atmos. Environ., 36, 46274634, doi:10.1016/S1352-2310(02)00460-0, 1999.

Barnes, I., Hjorth, J., and Mihalopoulos, N.: Dimethyl sulfide and dimethyl sulfoxide and their oxidation in the atmosphere, Chem. Rev., 106, 940-975, doi:10.1021/cr020529, 2006.

Bates, T. S., Calhoun, J. A., and Quinn, P. K.: Variations in the methanesulfonate to sulfate molar ratio in submicrometer marine aerosol particles over the South Pacific Ocean, J. Geophys. Res., 97, 9859-9865, 1992.

Berresheim, H., Andreae, M. O., Iverson, R. L., and Li, S. M.: Seasonal variations of dimethylsulfide emissions and atmospheric sulfur and nitrogen species over the western North Atlantic Ocean, Tellus B, 43, 353-372, 1991.

Boucher, O., Pham, M., and Venkataraman, C.: Simulation of the atmospheric sulfur cycle in the Laboratoire de Météorologie Dynamique General Circulation Model. Model description, model evaluation, and global and European budgets, Note scientifique IPSL du pôle de modélisation du climat, http://www.ipsl.jussieu. fr/poles/Modelisation/NotesSciences.htm, last access: 2009, 2002.

Boucher, O., Moulin, C., Belviso, S., Aumont, O., Bopp, L., Cosme, E., von Kuhlmann, R., Lawrence, M. G., Pham, M., Reddy, M. S., Sciare, J., and Venkataraman, C.: DMS atmospheric concentrations and sulphate aerosol indirect radiative forcing: a sensitivity study to the DMS source representation and oxidation, Atmos. Chem. Phys., 3, 49-65, 2003, http://www.atmos-chem-phys.net/3/49/2003/.

Campolongo, F., Saltelli, A., Jensen, N. R., Wilson, J., and Hjorth, J.: The role of multiphase chemistry in the oxidation of dimethylsulphide (DMS): A latitude dependent analysis, J. Atmos. Chem., 32, 327-356, 1999.

Castebrunet, H.: Soufre atmosphérique et changements climatiques : une étude de modélisation aux moyennes et hautes latitudes Sud, PhD thesis, Université Joseph FourierGrenoble, France, http://tel.archives-ouvertes.fr/docs/00/18/79/ 47/PDF/these_castebrunet.pdf, last access: September 2009,
2007.

Castebrunet, H., Genthon, C., and Martinerie, P.: Sulfur cycle at Last Glacial Maximum: Model results versus Antarctic ice core data, Geophys. Res. Lett., 33, L22711, doi:10.1029/ 2006GL027681, 2006.

CESOA: Cycle atmosphérique du soufre en relation avec le climat aux moyennes et hautes latitudes Sud, http://cesoa.mediasfrance. org/, last access: November 2008, 2007.

Chen, G., Davis, D. D., Kasibhatla, P., Bandy, A. R., Thornton, D. C., Huebert, B. J., Clarke, A. D., and Blomquist, B. W.: A study of DMS oxidation in the tropics: comparison of Christmas Island field observations of DMS, $\mathrm{SO}_{2}$, and DMSO with Model Simulations, J. Atmos. Chem., 37, 137-160, doi:10.1023/A: $1006429932403,2000$.

Chin, M., Savoie, D. L., Huebert, B. J., Bandy, A. R., Thornton, D. C., Bates, T. S., Quinn, P. K., Saltzman, E. S., and De Bruyn, W. J.: Atmospheric sulfur cycle simulated in the global model GOCART: Comparison with field observations and regional budgets, J. Geophys. Res., 105, 24689-24712, 2000.

Cosme, E., Genthon, C., Martinerie, P., Boucher, O., and Pham, M.: The sulfur cycle at high-southern latitudes in the LMD-ZT General Circulation Model, J. Geophys. Res., 107, 4690, doi: 10.1029/2002JD002149, 2002.

Cosme, E., Houdin, F., Genthon, C., and Martinerie, P.: Origin of dimethylsulfide, non-sea-salt sulfate, and methanesulfonic acid in eastern Antarctica, J. Geophys. Res., 110, D03302, doi:10. 1029/2004JD004881, 2005.

Davis, D., Chen, G., Kasibhatla, P., Jefferson, A., Tanner, D., Eisele, F., Lenschow, D., Neff, W., and Berresheim, H.: DMS oxidation in the Antarctic marine boundary layer: Comparison of model simulations and field observations of DMS, DMSO, $\mathrm{DMSO}_{2}$, $\mathrm{H}_{2} \mathrm{SO}_{4}(\mathrm{~g}), \mathrm{MSA}(\mathrm{g})$ and MSA(p), J. Geophys. Res., 103, 1657$1678,1998$.

de Bruyn, W. J., Harvey, M., Cainey, J. M., and Saltzman, E. S.: DMS and $\mathrm{SO}_{2}$ at Baring Head, New Zealand: implications for the yield of $\mathrm{SO}_{2}$ from DMS, J. Atmos. Chem., 41, 189-209, 2002.

de Mora, S. J., Wylie, D. J., and Dick, A. L.: Methanesulphonate and non-sea salt sulphate in aerosol, snow and ice on the east Antarctic plateau, Antarc. Sci., 9(1), 46-55, 1997.

Delmas, R. J., Wagnon, P., Goto-Azuma, K., Kamiyama, K., and Watanabe, O.: Evidence for the loss of snow-deposited MSA to the interstitial gaseous phase in central Antarctic firn, Tellus B, 55, 71-79, 2003.

Gershenzon, M., Davidovits, P., Jayne, J. T., Kolb, C. E., and Worsnop, D. R.: Simultaneous uptake of DMS and ozone on water, J. Phys. Chem. A., 105, 7031-7036, 2001.

Gondwe, M., Krol, M., Klaassen, W., Gieskes, W., and de Baar, H.: Comparison of modeled versus measured MSA:nss $\mathrm{SO}_{4}^{2-}$ ratios: A global analysis, Global Biogeochem. Cy., 18, GB2006, doi:10.1029/2003GB002144, 2004.

Hynes, A. J., Wine, P. H., and Semmes, D. H.: Kinetics and mechanism of $\mathrm{OH}$ reactions with organic sulfides, J. Phys. Chem., 90, 4148-4156, 1986.

IPCC: Climate change 2007, summary for policymakers, in: Climate change 2007: the physical science basis. Contribution of working group I to the fourth assessment report of the Intergovernmental Panel on Climate Change, edited by: Solomon, S., Qin, D., Manning, M., Chen, Z., Marquis, M., Averyt, K. B., 
Tignor, M., and Miller, H. L., Cambridge University Press, Cambridge, UK and New York, NY, USA, http://www.ipcc.ch/pdf/ assessment-report/ar4/wg1/ar4-wg1-spm.pdf, September 2009, 2007.

Jefferson, A., Tanner, D. J., Eisele, F. L., Davis, D. D., Chen, G., Crawford, J., Huey, J. W., Torres, A. L., and Berresheim, H.: $\mathrm{OH}$ photochemistry and methane sulfonic acid formation in the coastal Antarctic boundary layer, J. Geophys. Res., 103, 16471656, doi:10.1029/97JD02376, 1998.

Jones, A. E., Wolff, E. W., Ames, D., Bauguitte, S. J.-B., Clemitshaw, K. C., Fleming, Z., Mills, G. P., Saiz-Lopez, A., Salmon, R. A., Sturges, W. T., and Worton, D. R.: The multi-seasonal $\mathrm{NO}_{\mathrm{y}}$ budget in coastal Antarctica and its link with surface snow and ice core nitrate: results from the CHABLIS campaign, Atmos. Chem. Phys. Discuss., 7, 4127-4163, 2007,

http://www.atmos-chem-phys-discuss.net/7/4127/2007/.

Jourdain, B. and Legrand, M.: Seasonal variations of atmospheric dimethylsulfide, dimethylsulfoxide, sulfur dioxide, methanesulfonate, and non-sea-salt sulfate aerosols at Dumont d'Urville (coastal Antarctica) (December 1998 to July 1999), J. Geophys. Res., 106, 14391-14408, doi:10.1029/2000JD900841, 2001.

Jourdain, B., Preunkert, S., Cerri, O., Castebrunet, H., Udisti, R., and Legrand, M.: Year-round record of size-segregated aerosol composition in central Antarctica (Concordia station): Implications for the degree of fractionation of sea-salt particles, J. Geophys. Res., 113, D14308, doi:10.1029/2007JD009584, 2008.

Kärkäs, E., Teinilä, K., Virkkula, A., and Aurela, M.: Spatial variations of surface snow chemistry during two austral summers in western Dronning Maud Land, Antarctica, Atmos. Environ., 39, 1405-1416, doi:10.1016/j.atmosenv.2004.11.027, 2005.

Karl, M., Gross, A., Leck, C., and Pirjola, L.: Intercomparison of dimethylsulfide oxidation mechanisms for the marine boundary layer: gaseous and particulate sulphur constituents, J. Geophys. Res., 112, D15304, doi:10.1029/2006JD007914, 2007.

Kerminen, V.-M., Hillamo, R. E., and Wexler, A. S.: Model simulations on the variability of particulate MSA to non-sea-salt sulfate ratio in the marine environment, J. Atmos. Chem., 30, 345-370, 1998.

Kettle, A. J., Andreae, M. O., Amouroux, D., Andreae, T. W., Bates, T. S., Berresheim, H., Bingemer, H., Boniforti, R., Curran, M. A. J., DiTullio, G. R., Helas, G., Jones, G. B., Keller, M. D., Kiene, R. P., Leck, C., Levasseur, M., Malin, G., Maspero, M., Matrai, P., McTaggart, A. R., Mihalopoulos, N., Nguyen, B. C., Novo, A., Putaud, J. P., Rapsomanikis, S., Roberts, G., Schebeske, G., Sharma, S., Simó, R., Staubes, R., Turner, S., and Uher, G.: A global database of sea surface dimethylsulfide (DMS) measurements and a procedure to predict sea surface DMS as function of latitude, longitude and month, Global Biogeochem. Cy., 13, 399-444, 1999.

Koga, S. and Tanaka, H.: Modeling the methanesulfonate to nonsea-salt sulfate molar ratio and dimethylsulfide oxidation in the atmosphere, J. Geophys. Res., 104(D11), 13735-13747, doi:10. 1029/1999JD900069, 1999.

Krinner, G. and Genthon, C.: GCM simulations of the Last Glacial Maximum surface climate of Greenland and Antarctica, Clim. Dynam., 14, 741-758, doi:10.1007/s003820050252, 1998.

Krinner, G., Genthon, C., Li, Z.-X., and Le Van, P.: Studies of the Antarctic climate with a streched-grid general circulation model, J. Geophys. Res., 102, 13731-13745, 1997.
Kukui, A., Borissenko, D., Laverdet, G., and Le Bras, G.: Gasphase reactions of $\mathrm{OH}$ radicals with dimethyl sulfoxide and methane sulfinic acid using turbulent flow reactor and chemical ionization mass spectrometry, J. Phys. Chem. A., 107, 57325742, doi:10.1021/jp0276911, 2003.

Legrand, M. and Pasteur, E. C.: Methane sulfonic acid to non-seasalt sulfate ratio in coastal Antarctic aerosol and surface snow, J. Geophys. Res., 103, 10991-11006, doi:10.1029/98JD00929, 1998.

Legrand, M., Feniet-Saigne, C., Saltzmann, E. S., and Germain, C.: Spatial and temporal variations of methanesulfonic acid and non sea salt sulfate in Antarctic ice, J. Atmos. Chem., 14, 245-260, doi:10.1007/BF00115237, 1992.

Legrand, M., Hammer, C., De Angelis, M., Savarino, J., Delmas, R., Clausen, H., and Johnsen, S. J.: Sulfur-containing species (methanesulfonate and $\mathrm{SO}_{4}$ ) over the last climatic cycle in the Greenland Ice Core Project (central Greenland) ice core, J. Geophys. Res., 102, C12, 26663-26679, 1997.

Legrand, M., Sciare, J., Jourdain, B., and Genthon, C.: Subdaily variations of atmospheric dimethylsulfide, dimethylsulfoxide, methanesulfonate and non-sea-salt sulfate aerosols in the atmospheric boundary layer at Dumont D'Urville (coastal Antarctica) during summer, J. Geophys. Res., 106, 14409-14422, doi: 10.1029/2000JD900840, 2001.

Li, S.-M. and Barrie, L. A.: Biogenic sulfur aerosol in the Arctic troposphere: 1. Contributions to total sulfate, J. Geophys. Res, 98, 20613-20622, 1993.

Liss, P. S. and Merlivat, L.: Air-sea gas exchange rates: introduction and synthesis, in: The role of air-sea exchange in geochemical cycling, edited by: Buat-Menard, P., NATO ASI Ser. C Vol. 185, 113-127, Reidel, Dordrecht, The Netherlands, 1986.

Lucas, D. D. and Prinn, R. G: Mechanistic studies of dimethylsulfide oxidation products using an observationally constrained model, J. Geophys. Res., 107(D14), 4201, doi:10.1029/ 2001JD000843, 2002.

Lucas, D. D. and Prinn, R. G: Sensitivities of gas-phase dimethylsulfide oxidation products to the assumed mechanisms in a chemical transport model, J. Geophys. Res., 110, D21312, doi: 10.1029/2004JD005386, 2005.

Martinez, R. I. and Herron, J. T.: Stopped-flow study of the gasphase reaction of ozone with organic sulfides: Dimethyl sulfide, Int. J. Chem. Kinet., 10, 433-452, 1978.

Mauldin, R. L. III, Kosciuch, E., Henry, B., Eisele, F. L., Shetter, R., Lefer, B., Chen, G., Davis, D., Huey, G., and Tanner, D.: Measurements of $\mathrm{OH}, \mathrm{HO}_{2}+\mathrm{RO}_{2}, \mathrm{H}_{2} \mathrm{SO}_{4}$, and MSA at the South Pole during ISCAT 2000, Atmos. Environ., 38, 5423-5437, doi: 10.1016/j.atmosenv.2004.06.031, 2004.

Mauldin, R. L. III, Tanner, D. J., Heath, J. A., Huebert, B. J., and Eisele, F. L.: Observations of $\mathrm{H}_{2} \mathrm{SO}_{4}$ and MSA during PEM-Tropics-A, J. Geophys. Res., 104, 5801-5816, doi: 10.1029/98JD02612, 1999.

Mihalopoulos, N., Stephanou, E., Kanakidou, M., Pilitsidis, S., and Bousquet, P.: Tropospheric aerosol ionic composition in the Eastern Mediterrenean region, Tellus, 49B, 314-326, 1997.

Minikin, A., Legrand, M., Hall, J., Wagenbach, D., Kleefeld, C., Wolff, E., Pasteur, E. C., and Ducroz, F.: Sulfur-containing species (sulfate and methanesulfonate) in coastal Antarctic aerosol and precipitation, J. Geophys. Res., 103, 10975-10990, 1998. 
Müller, J.-F. and Brasseur, G. P.: IMAGES: A three-dimensional chemical transport model of the global troposphere, J. Geophys. Res., 100, 16455-16490, 1995.

Mulvaney, R., Pasteur, E. C., Peel, D. A., Saltzman, E. S., and Whung, P.-Y.: The ratio of MSA to non-sea-salt sulphate in Antarctic Peninsula ice cores, Tellus, 44, 295-303, doi:10.1034/ j.1600-0889.1992.t01-2-00007.x, 1992.

NOAA-PMEL: Global surface seawater dimethylsulfide (DMS) database, http://saga.pmel.noaa.gov/dms/, last access: September 2009, 2009.

Pasteur, E. C. and Mulvaney, R.: Migration of methane sulfonate in Antarctic firn and ice, J. Geophys. Res., 105, 11525-11534, 2000.

Pham, M., Müller, J.-F., Brasseur, G., Granier, C., and Mégie, G.: A three-dimensional study of the tropospheric sulfur cycle, J. Geophys. Res., 100, 26061-26092, 1995.

Piel, C., Weller, R., Huke, M., and Wagenbach, D.: Atmospheric methane sulfonate and non-sea salt sulfate records at the European Project for Ice Coring in Antarctica (EPICA) deep-drilling site in Dronning Maud Land, Antarctica, J. Geophys. Res., 111, D03304, doi:10.1029/2005JD006213, 2006.

Preunkert, S., Legrand, M., Jourdain, B., Moulin, C., Belviso, S., Kasamatsu, N., Fukuchi, M., and Hirawake T.: Interannual variability of dimethylsulfide in air and seawater and its atmospheric oxidation by-products (methanesulfonate and sulfate) at Dumont d'Urville, coastal Antarctica (1999-2003), J. Geophys. Res., 112, D06306, doi:10.1029/2006JD007585, 2007.

Preunkert, S., Jourdain, B., Legrand, M., Udisti, R., Becagli, S., and Cerri, O.: Seasonality of sulfur species (dimethyl sulfide, sulfate, and methanesulfonate) in Antarctica: Inland versus coastal regions, J. Geophys. Res., 113, D15302, doi:10.1029/ 2008JD009937, 2008.

Ravishankara, A. R., Rudich, Y., Talukdar, R., and Barone, S. B.: Oxidation of atmospheric reduced sulphur compounds: perspective from laboratory studies, Phil. Trans. R. Soc. Lond. B., 352, 171-182, doi:10.1098/rstb.1997.0012, 1997.

Read, K. A., Lewis, A. C., Salmon, R. A., Jones, A. E., and Bauguitte, S.: $\mathrm{OH}$ and halogen influence on the variability of nonmethane hydrocarbons in the Antarctic Boundary Layer, Tellus B, 59, 22-38, doi:10.1111/j.1600-0889.2006.00227.x, 2007.

Read, K. A., Lewis, A. C., Bauguitte, S., Rankin, A. M., Salmon, R. A., Wolff, E. W., Saiz-Lopez, A., Bloss, W. J., Heard, D. E., Lee, J. D., and Plane, J. M. C.: DMS and MSA measurements in the Antarctic Boundary Layer: impact of $\mathrm{BrO}$ on MSA production, Atmos. Chem. Phys., 8, 2985-2997, 2008, http://www.atmos-chem-phys.net/8/2985/2008/.

Saiz-Lopez, A., Mahajan, A. S., Salmon, R. A., Bauguitte, S. J.B., Jones, A. E., Roscoe, H. K., and Plane, J. M. C.: Boundary layer halogens in coastal Antarctica, Science, 317, 348-351, doi: 10.1126/science.1141408, 2007.

Saltzman, E. S.: Ocean/atmosphere cycling of dimethylsulfide, in: Ice core studies of global biogeochemical cycles, edited by: R. J. Delmas, NATO ASI Series I, 30, 65-89, 1995.

Saltzman, E. S., Savoie, D. L., Prospero, J. M., and Zika, R. G.: Methanesulfonic acid and non-sea-salt sulfate in Pacific ocean: Regional and seasonal variations, J. Atmos. Chem., 4, 227-240, 1986.

Sander, S. P., Friedl, R. R., Golden, D. M., Kurylo, M. J., Moortgat, G. K., Keller-Rudek, H., Wine, P. H., Ravishankara, A. R.,
Kolb, C. E., Molina, M. J., Finlayson-Pitts, B. J., Huie, R. E. and Orkin, V. L.: Chemical kinetics and photochemical data for use in atmospheric studies - Evaluation number 15, http: //jpldataeval.jpl.nasa.gov/, last access: June 2007, 2006.

Savoie, D. L., Arimoto, R., Keene, W. C., Prospero, J. M., Duce, R. A., and Galloway, J. N.: Marine biogenic and anthropogenic contributions to non-sea-salt sulfate in the marine boundary layer over the North Atlantic Ocean, J. Geophys. Res., 107(D18), 4356, doi:10.1029/2001JD000970, 2002.

Savoie, D. L. and Prospero, J. M.: Comparison of oceanic and continental sources of non-sea-salt sulphate over the Pacific Ocean, Nature, 339, 685-687, doi:10.1038/339685a0, 1989.

Savoie, D. L., Prospero, J. M., Larsen, R. J., and Saltzman, E. S.: Nitrogen and sulfur species in aerosols at Mawson, Antarctica, and their relationship to natural radionucleides, J. Atmos. Chem., 14, 181-204, 1992.

Sciare, J., Kanakidou, M., and Mihalopoulos, N.: Diurnal and seasonal variation of atmospheric dimethylsulfoxide at Amsterdam Island in the Southern Indian Ocean, J. Geophys. Res., 105, 17257-17265, 2000.

Seinfeld, J. H. and Pandis, S. N.: Atmospheric chemistry and physics: air pollution to climate, Wiley, New York, USA, 1326 pp., 1998.

Simpson, W. R., von Glasow, R., Riedel, K., Anderson, P., Ariya, P., Bottenheim, J., Burrows, J., Carpenter, L. J., Frieß, U., Goodsite, M. E., Heard, D., Hutterli, M., Jacobi, H.-W., Kaleschke, L., Neff, B., Plane, J., Platt, U., Richter, A., Roscoe, H., Sander, R., Shepson, P., Sodeau, J., Steffen, A., Wagner, T., and Wolff, E.: Halogens and their role in polar boundary-layer ozone depletion, Atmos. Chem. Phys., 7, 4375-4418, 2007, http://www.atmos-chem-phys.net/7/4375/2007/.

Taylor, K. E., Williamson, D., and Zwiers, F.: The sea surface temperature and sea-ice concentration boundary conditions for AMIP II simulations, PCMDI Report, 60, University of California, Livermore, USA, http://www-pcmdi.llnl.gov/publications/ pdf/60.pdf, last access: 2007, 2000.

Udisti, R., Becagli, S., Benassai, S., Castellano, E., Fattori, I., Innocenti, M., Migliori, A., and Traversi, R.: Atmosphere snow interaction by a comparison between aerosol and uppermost snowlayers composition at Dome C, East Antarctica, Ann. Glaciol., 39, 53-61, 2004a.

Udisti, R., Becagli, S., Benassai, S., de Angelis, M., Hansson, M. E., Jouzel, J., Schwander, J., Steffensen, J. P., Traversi, R., and Wolff, E.: Sensitivity of chemical species to climatic changes in the last $45 \mathrm{kyr}$ as revealed by high-resolution Dome C (East Antarctica) ice-core analysis, Ann. Glaciol., 39, 457-466, $2004 \mathrm{~b}$.

Urbanski, S. P., Stickel, R. E., and Wine, P. H.: Mechanistic and kinetic study of the gas-phase reaction of hydroxyl radical with dimethyl sulfoxide, J. Phys. Chem. A, 102, 10522-10529, 1998.

Virkkula, A., Teinilä, K., Hillamo, R., Kerminen, V. M., Saarikoski, S., Aurela, M., Viidanoja, J., Paatero, J., Koponen, I. K., and Kulmala, M.: Chemical composition of boundary layer aerosol over the Atlantic Ocean and at an Antarctic site, Atmos. Chem. Phys., 6, 3407-3421, 2006, http://www.atmos-chem-phys.net/6/3407/2006/.

von Glasow, R. and Crutzen, P. J.: Model study of multiphase DMS oxidation with a focus on halogens, Atmos. Chem. Phys., 4, 589608, 2004, http://www.atmos-chem-phys.net/4/589/2004/.

Wagner, T., Ibrahim, O., Sinreich, R., Frieß, U., von Glasow, R., 
and Platt, U.: Enhanced tropospheric BrO over Antarctic sea ice in mid winter observed by MAX-DOAS on board the research vessel Polarstern, Atmos. Chem. Phys., 7, 3129-3142, 2007, http://www.atmos-chem-phys.net/7/3129/2007/.

Wagnon, P., Delmas, R. J., and Legrand, M.: Loss of volatile acid species from upper firn layers at Vostok, Antarctica, J. Geophys. Res., 104, 3423-3431, 1999.

Weller, R. and Wagenbach, D.: Year-round chemical aerosol records in continental Antarctica obtained by automatic samplings, Tellus, 59, 755-765, doi:10.1016/S0009-2614(01) 00764-3, 2007.

Williams, M. B., Campuzano-Jost, P., Bauer, D., and Hynes, A. I.: Kinetic and mechanistic studies of the $\mathrm{OH}$-initiated oxidation of dimethylsulfide at low temperature - A reevaluation of the rate coefficient and branching ratio, Chem. Phys. Lett., 344, 61-67, doi:10.1016/S0009-2614(01)00764-3, 2001.
Wolff, E. W., Fischer, H., Fundel, F., Ruth, U., Twarloh, B., Littot, G. C., Mulvaney, R., Röthlisberger, R., de Angelis, M., Boutron, C. F., Hansson, M., Jonsell, U., Hutterli, M. A., Lambert, F., Kaufmann, P., Stauffer, B., Stocker, T. F., Steffensen, J. P., Bigler, M., Siggaard-Andersen, M. L., Udisti, R., Becagli, S., Castellano, E., Severi, M., Wagenbach, D., Barbante, C., Gabrielli, P., and Gaspari, V.: Southern Ocean sea-ice extent, productivity and iron flux over the past eight glacial cycles, Nature, 440, 491-496, doi:10.1038/nature04614, 2006.

Wolff, E. W., Hall, J. S., Mulvaney, R., Pasteur, E. C., Wagenbach, D., and Legrand, M.: Relationship between chemistry of air, fresh snow and firn cores for aerosol species in coastal Antarctica, J. Geophys. Res., 103, 11057-11070, 1998.

Yin, F., Grosjean, D., Flagan, R. C., and Seinfeld, J. H.: Photooxidation of dimethyl sulfide and dimethyl disulfide II: Mechanism evaluation, J. Atmos. Chem., 11, 365-399, 1990. 